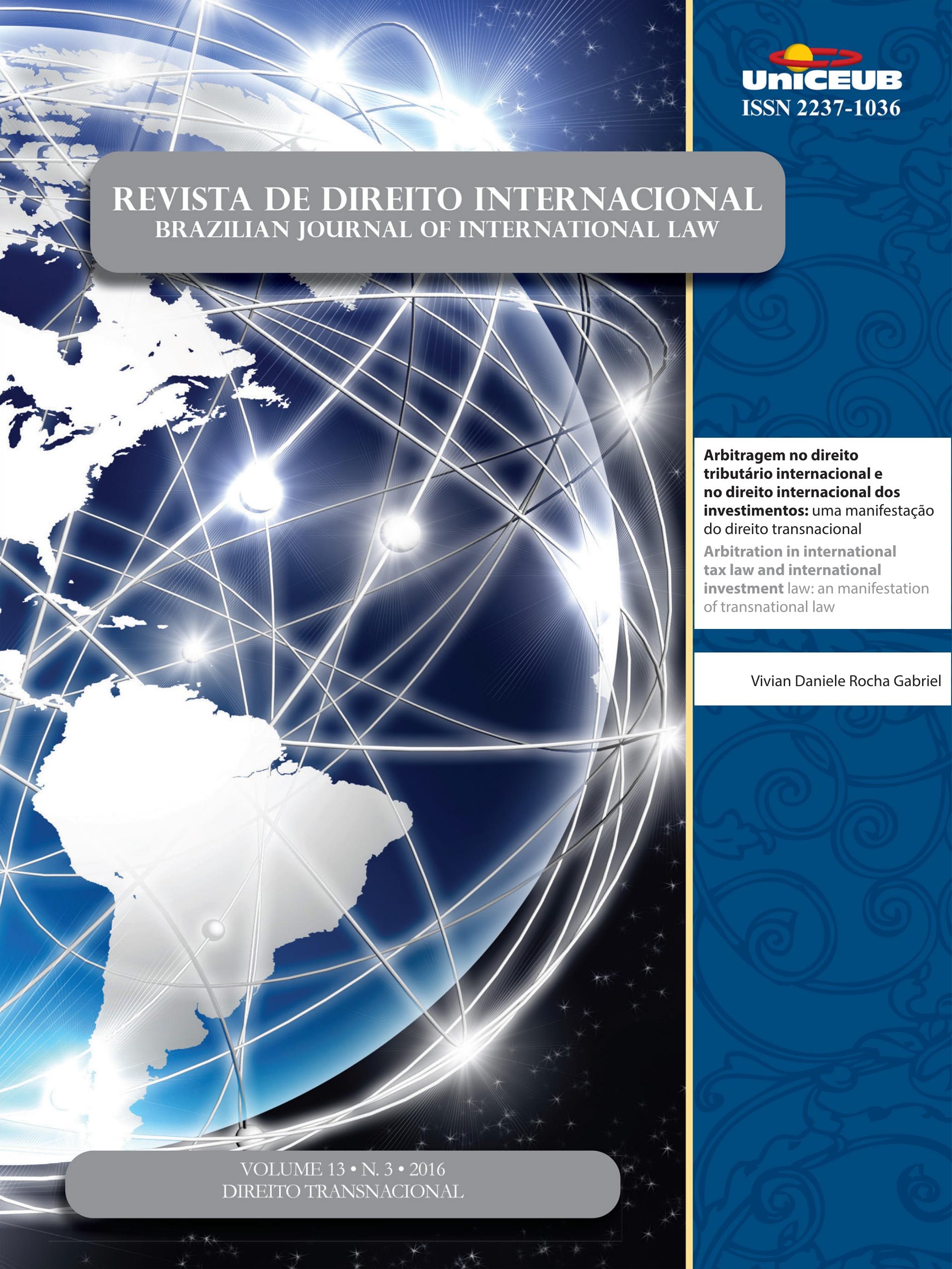


Crônicas da ATUALIdAde do direito internacional .................................................. 2

I. Dossiê Temático: Direito Transnacional .........................................................15

EDITORIAL: O Direito Transnacional - Circulação de normas e relações jurídicas transnacionais .......16 Priscila Pereira de Andrade

A emergênCia do direito transnacional ambiental .............................................18 Priscila Pereira de Andrade

Desafíos y RESPUESTAS TRANSNACIONALES FRENTE A LOS CRÍMENES AMBIENTALES ...............30 Rosmerlin Estupiñan-Silva

DiREITO TRANSNACIONAL E MUdANÇAS CLIMÁTICAS .50 Géraud de Lassus Saint-Geniès

Especies en movimiento: la Convención sobre el Comercio Internacional de Especies Amenazadas de Fauna y Flora Silvestres como espacio de “Encuentro” de discursos, ACTORES Y ESTRATEGIAS EN EL DERECHO AMBIENTAL TRASNACIONAL

María Valeria Berros e Dabel Leandro Franco

El carácter transnacional del Sistema comunitario de ECogestion « Eco-ManageMENT AND Audit SCHEME » (EMAS) DENTRo de LA UE y MÁs ALlÁ DE SUS Fronteras ......72 Adélie Pomade

O CONCEITO DE CONDUTA EMPRESARIAL RESPONSÁVEL À LUZ DOS ORDENAMENTOS JURÍDICOS BRASILEIRO, INTERNACIONAL E TRANSNACIONAL

Gabriel Webber Ziero

ARBITRAGEM NO DIREITO TRIBUTÁRIO INTERNACIONAL E NO DIREITO INTERNACIONAL DOS INVESTIMENTOS: UMA MANIFESTAÇÃO DO DIREITO TRANSNACIONAL

Vivian Daniele Rocha Gabriel 
O DIREITO TRIBUTÁRIO SOB UMA PERSPECTIVA TRANSNACIONAL

Franciele de Simas Estrela Borges

As Características do Direito Transnacional como Metodologia: Análise sob o enfoQue dos Aspectos Processuais da Arbitragem 126

Flávia Foz Mange

O DIREITO TRANSNACIONAL (“GLOBAL LAW") E A CRISE DE PARADIGMA DO ESTADO-CENTRISMO: É POSSÍVEL CONCEBER UMA ORDEM JURÍDICA TRANSNACIONAL? ...................................... 146

Luiza Nogueira Barbosa e Valesca Raizer Borges Moschen

TransPorte AÉREO E DIREITO TRANSNACIONAL: DA CONVERGÊNCIA À UNIFORMIDADE 160 Mickael R. Viglino

Outros Artigos. 175

O Fundo Monetário Internacional e a proteção dos direitos humanos: uma análise DO PROGRAMA DE CRESCIMENTO E REDUÇÃO DA POBREZA NO HAITI 177

Pablo Henrique Hubner de Lanna Costa e Carlos Alberto Simões de Tomaz

Um estranho no ninho? Padrões privados no Acordo de Barreiras Técnicas ao CoMÉRCIO DA OMC 192

Michelle Ratton Sanchez Badin e Marina Yoshimi Takitani

Os benefícios tributários do programa Inovar-Auto e os princípios da Nação Mais Favorecida e do Tratamento Nacional: uma análise dos argumentos dos Painéis atualmente em Curso contra o Brasil no Órgão de SoluÇão de Controvérsias da OMC . 211 Eric Moraes Castro e Silva

A ERA DA HUMANIDADE: REFLEXões PARA A HISTÓRIA DO DIREITO INTERNACIONAL 236 Henrique Weil Afonso

Precedentes vinculantes nos Estados Unidos da América e no direito brasileiro: Um ESTUDO COMPARADO 264

Patrícia Perrone Campos Mello 
IL DIRITTO AMBIENTALE SECONDO L'OTTICA DEL DIRITTO COSTITUZIONALE POSITIVO E LA RESPONSABILITÀ PER DANNI ALL'AMBIENTE NEL DIRITTO COMUNITARIO: LO STATO DELL'ARTE DEL DIRITTO AMBIENTALE COSTITUZIONALE E COMUNITARIO 287

Elcio Nacur Rezende

DA DESCONSIDERAÇÃo DA PERSONALIDADE JURÍDICA NAS RELAÇÕES CONSUMEIRISTAS BRASILEIRAS: ANÁLISE À LUZ DAS TEORIAS CLÁSSICAS

Daniel Amin Ferraz e Marcus Vinicius Silveira de Sá

ANALYSIS OF ADVANTAGES AND DISADVANTAGES OF FORUMS PRESCRIBED UNDER THE UNCLOS AND STATE PRACTICE: THE WAY AHEAD FOR INDIA ......................................................319

Vinai Kumar Singh

Do governo POR LEIS À governanÇA POR NúMERos: breve anÁlise do Trade in SERVICE AgreEMENT (TISA) ...............................................................................338 Jânia Maria Lopes Saldanha, Rafaela da Cruz Mello e Têmis Limberger

As DIRETIVAS EUROPEIAS COMO NORMA REGULADORA DO DIREITO ADMINISTRATIVO GLOBAL ..356 Alice Rocha da Silva e Ruth Maria Pereira dos Santos

O desenVolvimento da POlítica AGRícola COMUM dA UNião EUROPEIA 375 Tatiana de A. F. R. Cardoso Squeff

A imunidade de Jurisdição das organizaÇões internacionais FaCE AO Direito de aCESSO À JUSTIÇA 391

Fernanda Araújo Kallás e Caetano

O DIREITO INTERNACIONAL ENTRE O DEVER ÉTICO E A AÇÃo POLÍ́TICA: OS FUNDAMENTOS DE UM DEVER DE COOPERAÇÃO INTERNACIONAL NA FILOSOFIA POLÍTICA DE IMMANUEL KANT .405 Ademar Junior Pozzatti

EXTENSÃo E FRAGMENTAÇÃo NO CONTEXTO DA JURISDIÇÃO PENAL INTERNACIONAL .423 Marcus Vinícius Xavier de Oliveira

A DEFINiÇÃo JURÍdiCA DA "COMUNIDADE" .444 Nitish Monebhurrun, Michelle Lucas Cardoso Balbino, Fernanda Castelo Branco Araujo, Othon Pantoja, Míara Bogo Bruno e Cândida Dettenborn Nóbrega 
Comparative Study on Chinese Local Legislation of Science and Technology ProGRESS

LI Xiaoming e LI Yihan

O CONTROLE PENAL DO TRÁFICO DE PESSOAS: CONSTRUÇÃO JURÍDICA, INTERAÇÕES ORGANIZACIONAIS E COOPERAÇÃO INTERNACIONAL

Bruno Amaral Machado e Priscilla Brito Silva Vieira

Desativismo judicial: a extradição Battisti no Supremo Tribunal Federal .505 Francisco Rezek e Israel Paulino

A decisão norte-americana do Caso Myriad: novos paradigmas para a Proteção patenTÁRIA DO CÓDIGO GENÉTICO HUMANO E BIOTECNOLOGIA 514 José Carlos Vaz e Dias e Clarisse De La Cerda 


\title{
Arbitragem no direito tributário internacional e no direito internacional dos investimentos: uma manifestação do direito transnacional*
}

\author{
Arbitration in international tax law \\ and international investment law: an \\ manifestation of transnational law
}

Vivian Daniele Rocha Gabriel**

\section{Resumo}

O artigo visa analisar as áreas do Direito Tributário Internacional e do Direito Internacional dos Investimentos, bem como os meios de solução de controvérsias aplicados, como manifestações do Direito Transnacional, uma vez que em ambos há a proeminência de entes privados que circulam além de seu mero território nacional e que podem, potencialmente, influenciar as ordens jurídicas domésticas. Partindo-se desse pressuposto, o objetivo do artigo é, também, examinar o funcionamento do mecanismo arbitral de resolução de litígios nessas duas esferas do direito e como se dá seu acesso, pelo que se efetuará uma comparação entre as duas sistemáticas e realçando, quando houver, suas similaridades e a necessidade de mudanças, e qual é a posição brasileira a respeito. A metodologia empregada manifesta-se como teórica, bibliográfica, descritiva e exploratória. Em conclusão, pode-se afirmar que, tanto no Direito Tributário Internacional quanto no Direito dos Investimentos, em relação a ambas as modalidades de Direito Transnacional, deve haver o acesso direto do particular ao mecanismo arbitral, que perseguirá, diretamente, seus interesses sem que haja o entreposto estatal. $\mathrm{O}$ artigo se mostra original, devido à existência de poucas análises jurídicas recentes que trazem à baila esses dois âmbitos do Direito Internacional como partes integrantes de um Direito Transnacional, além de comparar seu sistema de solução de controvérsias.

Palavras-chave: Direito tributário internacional. Direito internacional dos investimentos. Arbitragem. Direito transnacional.

* Recebido em 15/07/2016 Aprovado em 10/09/2016

** Advogada. Doutoranda e Mestre em Direito Internacional e Comparado pela Faculdade de Direito do Largo de São Francisco da Universidade de São Paulo (USP).Advogada Pesquisadora do Centro de Estudos do Comércio Global e Investimentos (CCGI/FGV). E-mail: vivian.d.rocha@gmail.com

\section{Abstract}

The article aims to analyze the International Tax Law and International Investment Law areas, as well as the dispute settlement mechanisms applied in both, revealed such as manifestations of Transnational Law, since both of them have prominent private actors that act beyond national borders and can influence domestic juridical orders. Assuming that outlook, the purpose of the article is also to examine the functioning of the arbitration dispute 
settlement mechanism in both law spheres and how is the access to it, comparing and highlighting them, when it is possible, their similarities and the need to change, and which is the Brazilian position. The methodology adopted in the development of this research is bibliography, descriptive and exploratory. In conclusion, it can be affirmed that, in both International Tax Law and Investment Law, which are manifestation of Transnational Law, the private entities must have direct access to arbitral mechanism, pursuing directly their own interests without the need of the State. The article is original, because there are few recent legal studies on both International Law areas as part of a Transnational Law, beyond that there is also original the comparison of the dispute settlement systems.

Keywords: International tax law. International investment law. Arbitration. Transnational law.

\section{INTRODUÇÃo}

No mundo contemporâneo, as relações internacionais têm sido fundadas nas atividades das empresas transnacionais, que são, atualmente, os principais agentes globais e dinâmicos da economia mundial. Por atuarem em um mercado altamente competitivo, estas têm como interesse precípuo que todos os obstáculos impeditivos, sejam removidos ou, até mesmo, em último caso, atenuados. Ocorre que um dos principais desafios do Direito Internacional na atualidade trata-se, justamente, da "criação e sedimentação de sistemas normativos internacionais capazes de aumentar a segurança jurídica internacional, mediante a qual os fluxos econômicos no âmbito externo seriam facilitados pela redução de riscos e custos transacionais"1.

Assim, devido à complexidade das relações econômicas internacionais e da variedade de atores, sejam eles empresas, Estados ou indivíduos, o que se presencia é a propagação de um Direito que vai além das fronteiras nacionais e que regula, portanto, as ações transnacionais em busca de maior segurança jurídica à pluralidade de atores envolvidos nas mais complexas relações envolvendo duas ou mais entidades.

1 COSTA, José Augusto Fontoura. Proteção e promoção do investimento estrangeiro no Mercosul: uma ferramenta para a implementação de um bom clima de investimentos? Revista Brasileira de Politica Internacional, 49, n. 2, p. 60-77, 2006. p. 60.
A ação dos Estados se mostra relevante na seara internacional, pois, por intermédio de negociações internacionais, será possível analisar os pontos de convergência e de conflito nas relações e, por fim, se chegar a uma diretriz geral a ser seguida e cumprida, normalmente pela via de tratados e convenções internacionais.

Nesse diapasão, um dos principais instrumentos jurídicos internacionais que poderão cumprir essa lacuna e gerar maior segurança aos entes privados, em específico, aos investidores estrangeiros, são os acordos de promoção e proteção de investimentos estrangeiros, particularmente, na forma de tratados bilaterais de investimentos. Estes foram criados frente à necessidade de proteção aos investidores, que, muitas vezes, encontram óbices na ação estatal para o desenvolvimento e livre proliferação de seus capitais, como por exemplo, quando da ocorrência da obstrução na remessa de seus lucros ou na expropriação ou nacionalização de seus ativos, a exemplo do que ocorreu com a nacionalização dos ativos da Petrobras na Bolívia em 2006².

Um outro elemento que se mostra relevante nessa atuação internacional é a tributação, de acordo com a categorização direta ou indireta, que incide nos produtos e serviços exportados e nas próprias empresas. Nesse contexto, reside o conceito de soberania fiscal, em que cada Estado, no âmbito de seu território e de acordo com seus critérios constitucionais, se encontra apto a instituir o sistema tributário que melhor convir com os seus interesses. Desse modo, inserem-se os acordos para se evitar a dupla tributação, que possuem como finalidade precípua evitar a dupla exigência de tributação relacionada a determinado fato gerador, o que se conecta, diretamente, com a busca da estabilização das relações, uma vez que os agentes envolvidos buscam, sempre, pela maximização de suas oportunidades e pela redução de riscos e de perdas.

As convenções para evitar a dupla tributação e os acordos para proteção e promoção de investimentos, portanto, têm o papel de estabelecer diretrizes a serem seguidas de modo a tentar estabilizar as relações internacionais e a condição dos investidores e contribuintes. Entretanto, caso haja violação desses tratados, os mecanismos de solução de controvérsias neles previstos serão acionados para que se reduza os efeitos disruptores.

2 RIBEIRO, Marilda Rosado de Sá. Sovereignty over natural resources investment law and expropriation: the case of Bolivia and Brazil. The Journal of World Energy Law and Business, Oxford, v. 2, n. 2, p. 129-148, July 2009. p. 132. 
Nesse sentido, o presente artigo pretende fazer um estudo interdisciplinar englobando tanto o Direito Tributário Internacional quanto o Direito Internacional dos Investimentos como manifestações legítimas do Direito Transnacional, que se trata de uma vertente jurídica direcionada a gerir e trazer maior estabilidade a fatos transnacionais, em especial, no contexto dos investimentos e da tributação. Será dada ênfase aos meios de solução de controvérsias previstos nas convenções para evitar a dupla tributação, quais sejam o procedimento amigável e, em especial, a arbitragem, e, em seguida, à arbitragem de investimentos realizada pelo mecanismo do Banco Mundial, que, apesar de não ser o único método para resolver litígios nesta matéria, ganhou destaque nos últimos anos.

Em seguida, será particularizado o posicionamento brasileiro quanto ao sistema arbitral tributário e ao sistema tradicional de arbitragem de investimentos. É nesse contexto justamente que se encontra a problemática do artigo, qual seja a posição de resistência do Brasil quanto a esses mecanismos arbitrais de solução de controvérsias, o que denota, consequentemente, a relutância também ao Direito Transnacional. Ainda, se coloca em questionamento o acesso do indivíduo tanto no sistema arbitral tributário internacional quanto no dos investimentos, pelo que se argumenta que o particular é legítimo para este acesso.

Para isso, serão comparados ambos os ramos do direito, que, apesar de serem subáreas distintas, possuem pontos de contato que serão descritos. Serão apresentadas, também, algumas críticas comuns quanto à posição brasileira de afastamento quanto a estes mecanismos arbitrais, principalmente, em razão do bloqueio do acesso do particular a esses sistemas de solução de controvérsias.

\section{Direito Transnacional}

Atualmente, verifica-se que o mundo passa por um fenômeno de constante transformação, em particular, no que se refere à construção de relações, sejam elas pessoais, sejam elas comerciais, que vão além das fronteiras dos Estados, criando um emaranhado complexo de situações que exigem respostas jurídicas. Essa circunstância pode ser explicada por intermédio do que se denomina Direito Transnacional.
Nesse contexto, o Estado nacional não é mais o sujeito único das relações políticas, sociais e econômicas que pairam no cenário internacional. Esse atua em certas atividades que transcendem os limites dos Estados concomitantemente com indivíduos, empresas, organizações de Estados e outros grupos ${ }^{3}$. Essas atividades, por sua vez, abarcam um conjunto de relações que vêm ultrapassar os limites do território, da nacionalidade e da soberania, cada qual com sua complexidade.

Tais relações implicam riscos, tais como políticos, econômicos, financeiros, dentre outros, que podem ser analisados separadamente, contudo, de acordo com Ian Bremmer e Preston Keat, facilmente, um desses riscos poderá gerar o outro, levando, inclusive, a consequências jurídicas. Exemplo disso é o caso da nacionalização do Canal de Suez, em 1956, em que um evento político e econômico, a nacionalização do Canal por Gamal Abdel Nasser, gerou impacto financeiro direto na empresa anglo-francesa que controlava o canal, implicando, portanto, em uma questão notadamente de cunho jurídico, tendo em conta os prejuízos causados pela ação estatal em uma empresa de capital binacional ${ }^{4}$.

Diante de questões transnacionais, envolvendo atores diversos e ações que terão consequências jurídicas explícitas que necessitam ser mitigadas, o direito clássico já não mais é suficiente para explicar ou solucionar tais situações. Depara-se, portanto, com a necessidade de um direito que garanta segurança jurídica nessas condições. Por isso, traz-se à baila o Direito Transnacional.

Este consubstancia-se em uma teoria explicativa em que, de acordo com a percepção de Phillip Jessup ${ }^{5}$, um dos primeiros autores a desenvolver essa nomenclatura e análise, parte-se do pressuposto de que, em um mundo global, a regulação das relações não mais se concentra, apenas, nos sistemas nacionais estatais, porém, devido à sua complexidade, à variedade de agentes e de situações, também há um direito além das fronteiras que, portanto, regula as ações transnacionais.

Em outras palavras, há, nesse caso, um conjunto de normas provenientes de diversas vertentes especializa-

3 JESSUP, Philip C. Direito transnacional. Rio de Janeiro: Fundo de Cultura, 1965. p. 13.

4 BREMMER, Ian; KEAT, Preston. The fat tail the power of political knowledge for strategic investing. Oxford: Oxford University, 2009. p. 6.

5 JESSUP, Philip C. Direito transnacional. Rio de Janeiro: Fundo de Cultura, 1965. p. 13 
das $^{6}$, proposto para reger as situações que envolvem vários atores e relações jurídicas que não são puramente nacionais, tampouco depreendem a aplicação pura e simples do Direito Internacional, uma vez que se deve ter em mente o pungente movimento da sociedade transnacional.

Jessup propugnava em sua obra "Direito Transnacional" de 1965, que a comunidade internacional desenvolvia laços, cada vez mais intricados, e o Direito Internacional também não mais atendia as exigências conceituais da época "para incluir todas as normas que regulam atos ou fatos que transcendem as fronteiras nacionais"7. Direito Transnacional. Portanto, tornar-se-ia o conceito mais adaptado à nova realidade, pois "tanto o direito público quanto o privado estão compreendidos, como estão outras [áreas] que não se enquadram inteiramente nessas categorias clássicas".

Portanto, explica-se o fenômeno da globalização e da complexidade das relações jurídicas por uma teoria que expõe e desenvolve que o direito não mais pode ser localista para resolver tais questões, mas deve ser analisado de forma ampla e global, sem se apegar às divisões clássicas, uma vez que as duas áreas, tanto a pública quanto a privada, envolvem o mesmo fenômeno relacional, que necessita de elucidação quando posto em cheque e, também, de fornecer segurança jurídica a todos os atores envolvidos.

Salienta-se que, nesse contexto (e para o presente estudo), inserem-se no Direito Transnacional, além dos Estados soberanos tanto os indivíduos quanto as empresas multinacionais, que atuam como principais agentes e forças motoras da integração comercial e da produção e que, por seu caráter distinto fomentam a complexidade nas relações jurídicas contemporâneas.

Quanto à empresa multinacional, esta promove relações jurídicas extraterritoriais por diversos fatores diretamente intrínsecos à sua atuação e razão de ser, como por exemplo, o aumento de sua competitividade e a maximização de seus lucros, por intermédio da busca de

6 Segundo Phillip Jessup: "O uso do Direito Transnacional forneceria uma fonte mais abundante de normas com que se guiar e seria desnecessário perguntar-se em certos casos se é Direito Público ou o Privado que se deve aplicar". JESSUP, Philip C. Direito transnacional. Rio de Janeiro: Fundo de Cultura, 1965. p. 21.

7 JESSUP, Philip C. Direito transnacional. Rio de Janeiro: Fundo de Cultura, 1965. p. 12.

8 JESSUP, Philip C. Direito transnacional. Rio de Janeiro: Fundo de Cultura, 1965. p. 12. novos mercados, de mão de obra menos custosa e de maior abundância e facilidade de obtenção de matérias-primas. Tudo isso faz com que a empresa transnacional se caracterize como o principal investidor estrangeiro internacional, o que faz com que circule frequentemente por diferentes ordenamentos jurídicos estatais.

Assim, nessa esfera, entre o nacional e o internacional, circula um direito de aspecto transnacional. Desse modo, o Direito Transnacional não se trata de um ramo de direito definido, classificação ou categorização definida, mas sim busca examinar essa normatização de relações jurídicas complexas além-fronteiras.

No entanto, "à medida que uma firma aumenta seus investimentos, os riscos de incorrer numa dada probabilidade de perda vão se tornando mais sérios" 9. Ao se investir além das fronteiras nacionais as incertezas levam a riscos recorrentes, que vão desde os riscos comerciais, relacionados às instabilidades da atividade econômica, até os não comerciais, como instabilidades políticas, decisões arbitrárias dos Estados e ações governamentais imprevisíveis, muitas vezes, prejudiciais aos atores envolvidos, no caso, as empresas transnacionais investidoras ${ }^{10}$.

Quando esses riscos evoluem e se materializam em prejuízos reais para um dos atores presentes na relação, algumas medidas devem ser tomadas de forma a mitigar os danos e dirimir os conflitos potenciais gerados entre as partes. O Direito Transnacional, dotado de sua característica extraterritorial, além de propor um arcabouço jurídico especializado, tem na arbitragem internacional o sistema de solução de controvérsias que mais se encaixa aos propósitos da comunidade internacional globalizada, visto que esta vai além do locus estatal, demonstrando-se mais imparcial e eficiente se comparada ao judiciário estatal doméstico dos Estados soberanos. Além disso, as autoridades estatais nem sempre lidam da melhor forma com situações transnacionais, seja por ausência de conhecimento mais apurado sobre a matéria, seja por não dominar a sistemática e as peculiaridades dos ordenamentos jurídicos em discussão, que trazem consequências distintas na aplicação e interpretação da norma.

9 PENROSE, Edith. A teoria do crescimento da firma. Campinas: Unicamp, 2006. p. 106.

10 ZIEGLER, Andreas R.; GRATTON, Louis-Philippe. Investment assurance In: MUCHLINSKI, Peter; ORTINO, Federico; SCHREUER, Christoph (Org.). The Oxford handbook of international investment law. Oxford: Oxford University, 2008. p. 524-548. 
Exemplo disso é a contextualização do Direito Transnacional à nova lex mercatória (conceito resgatado e posto em evidência por Berthold Goldman em 1964), em que há a regulação das transações internacionais por entes privados, por intermédio de modelos contratuais e da consolidação de práticas comerciais ${ }^{11}$. Nela, sobressai-se a arbitragem internacional comercial como mecanismo para resolução de litígios entre partes privadas. Nas palavras do doutrinador José Augusto Fontoura Costa,

a referência a um Direito transnacional nascido,
espontaneamente, dos costumes comerciais
e que se utiliza da arbitragem, bem como das
sanções reputacionais, para garantir sua aplicação
e cumprimento vem se constituindo em um
dos mais populares discursos a respeito da
transnacionalização de formas jurídicas como
suporte para a estabilização de relações comerciais ${ }^{12}$

Contudo, outras demandas surgem diante das relações jurídicas transnacionais, como no que tange a questões de cunho fiscal e aquelas relacionadas a investimentos estrangeiros. Como será explicitado mais adiante, tanto situações que envolvem particular e dois ou mais Estados que promovem dupla tributação da renda, quanto em ocasiões em que uma empresa multinacional se instala em território estrangeiro e neste sofre atentados contra sua propriedade ou tratamento discriminatório, por exemplo, verifica-se, também, a existência de relações que vão além das fronteiras nacionais originárias do particular. Nesse caso, este acaba sofrendo prejuízos de ordem econômica em decorrência de ações promovidas por outros Estados que não o seu de origem, no decorrer de uma relação transnacional. Entretanto, por envolverem questões muito globalizadas, inclusive nesses casos, os sistemas jurídicos estatais não mais são os únicos capazes de resolvê-las ou, então, esses podem não ser os mais eficazes para tanto, preferindo-se meios alternativos, como é o caso da arbitragem.

Nesse diapasão, partindo-se do pressuposto que, de acordo com o Direito Transnacional, como teoria explicativa, a arbitragem é um método de solução de contro-

11 COSTA, José Augusto Fontoura. A autonomia da nova lex mercatoria e a estabilização de relações comerciais internacionais. Revista do Instituto do Direito Brasileiro, v. 2, p. 4783-4810, 2013; STRENGER, Irineu. A arbitragem como modo de inserção de normas da lex mercatoria na ordem estatal. Revista Brasileira de Arbitragem, ano 1, n. 3, jul./set. 2004.

12 COSTA, José Augusto Fontoura. A autonomia da nova lex mercatoria e a estabilização de relações comerciais internacionais. Revista do Instituto do Direito Brasileiro, v. 2, p. 4783-4810, 2013. vérsias adequado para situações que vão além das fronteiras nacionais, busca-se saber se, quando encaixada em alguns sub-ramos específicos do Direito Internacional que tratam de questões jurídicas transnacionais que envolvam tributos e investimentos, quais sejam o Direito Tributário Internacional e o Direito Internacional dos Investimentos, cada qual com características e sistema de solução de controvérsias próprios também baseados na arbitragem, o particular deverá ter acesso direto a esse sistema.

\section{Direito tributário internacional e SOLUÇÃO DE CONTROVÉRSIAS}

Das normas veiculadas por tratados e convenções internacionais em matéria tributária podem decorrer, muitas vezes, conflitos interpretativos que acabam por frustrar o objetivo dos acordos. Nesse ínterim, pretende-se discorrer sobre a questão dos conflitos que surgem no âmbito do Direito Tributário Internacional e quais as soluções disponíveis para que estes sejam resolvidos.

\subsection{Conflitos no Direito Tributário Internacional}

No mundo contemporâneo, marcado por transformações constantes, o fenômeno da globalização trouxe consigo o aprofundamento das relações econômicas e comerciais. O que se observa é a distribuição de atividades em diferentes partes do globo e a fragmentação da produção, caracterizada principalmente por meio das cadeias globais de valor ${ }^{13}$, e a crescente integração das atividades econômicas e financeiras, as quais são dotadas de grande dinamicidade.

Essa nova realidade econômica também traz reflexos para o mundo jurídico e para a Novíssima Ordem Internacional, que segundo Marilda Rosado de Sá Ribeiro, "chega a formar, na época contemporânea, um novo direito transnacional ou cosmopolita, que consagra valores de boa-fé, respeito aos direitos individuais e novos

13 ORGANISATION FOR ECONOMIC CO-OPERATION AND DEVELOPMENT. Interconnected economies: benefiting from global value chains. OECD. 2013. Disponível em: < https://www. oecd.org/sti/ind/interconnected-economies-GVCs-synthesis. pdf $>$. Acesso em: 06 maio 2016. 
balizamentos para o exercício do poder Estatal"14. Em especial, para o Direito Tributário Internacional, a possibilidade de que diferentes países possam tributar as mesmas transações transfronteiriças ou a renda impulsiona a discussão no seio da comunidade internacional para que se alcancem meios para mitigação de seus efeitos.

Vale ressaltar que as normas de Direito Tributário Internacional detêm diversas funções diretamente relacionadas com a soberania dos Estados, quais sejam delimitar competências, aplicar leis, exigir tributos, exercer jurisdição sobre seu território, dentre outras. Assim, é possível que, em matéria tributária, em decorrência de seu exercício de soberania, os Estados se envolvam em questões que abranjam mais de um ordenamento jurídico nacional, o que, por consequência, resulta em conflitos jurídicos de caráter internacional. Em particular, esses conflitos normativos provenientes da sobreposição de regras de Estados distintos acabam por submeter a tributação de uma mesma riqueza simultaneamente. Este fenômeno resulta, portanto, na dupla tributação internacional o que merece a atenção de nosso estudo.

A dupla tributação internacional é definida por Klaus Vogel como a imposição de tributos em dois ou mais Estados ao mesmo contribuinte, no que diz respeito ao mesmo fato gerador e por períodos idênticos, decorrentes da troca de bens e serviços e do movimento de capitais e tecnologia ${ }^{15}$. Nesse sentido, destaca-se o advento das convenções internacionais para evitar a dupla tributação, criadas com o intuito de tratar internacionalmente da questão da sobreposição de competência tributária. Os principais objetivos destas convenções são, portanto: (i) evitar a dupla tributação; (ii) evitar a elisão fiscal; e (iii) impedir a discriminação fiscal ${ }^{16}$.

Historicamente, as discussões sobre a criação de tratados internacionais que regessem a matéria remontam à primeira metade do século XX. Em 1921, a extinta Liga das Nações encomendou à especialistas em finanças públicas um estudo sobre os efeitos da dupla tributação na economia, os quais demonstraram as con-

14 RIBEIRO, Marilda Rosado de Sá. Direito dos investimentos e o petróleo. Revista da Faculdade de Direito da UERJ, v. 1, p. 1-37, 2010. p. 05. 15 VOGEL, Klaus. On double Taxation Conventions: a commentay to the OECD, UN and U.S. Model Conventions for the Avoidance of Double Taxation of Income and Capital, With Particular Reference to German Treaty Practice. Boston: Kluwer, 1998, p.2.

16 OKUMA, Alessandra. As convenções para evitar dupla tributação e elisão fiscal e os meios de solução de controvérsias. In: TÔRRES, Heleno Taveira. Direito tributário internacional aplicado. São Paulo: Quartier Latin, 2007. v. 4. p. 410. sequências econômicas negativas provocadas por esse fenômeno em relação à alocação do fluxo de capitais, impedindo a distribuição equitativa dos encargos entre os contribuintes ${ }^{17}$. Nesse diapasão, engendrou-se a criação de convenções modelo para que regessem o direito de tributação transfronteiriça e de renda. Ao todo, em 1928, a Liga das Nações criou 6 modelos de convenção tributária, destes 4 contra a dupla imposição (3 referentes ao imposto de renda e de capital e 1 relativo ao imposto de herança) e 2 contra a evasão fiscal para os impostos anteriormente referidos, dentre estes últimos, 1 de assistência mútua na quantificação do imposto (troca de informações) e 1 de cooperação na cobrança do tributo (aplicação de decisões estrangeiras) ${ }^{18}$.

Ressalta-se, inclusive, que os 4 modelos de tratados contra a dupla tributação internacional editados pela Liga das Nações dispunham que quanto aos litígios decorrentes de sua interpretação ou aplicação deveriam ser resolvidos por negociação dos Fiscos interessados e, caso não fossem resolvidos, poderiam ser submetidos a um organismo técnico a ser indicado pelo Conselho da Liga das Nações, para fins de conciliação, pelo que suas conclusões não seriam obrigatórias (exceto se as parte assim conviessem). Ausente esse acordo, as partes poderiam encaminhar o litígio para a arbitragem ou recorrer a uma corte permanente, inclusive a Corte Permanente de Justiça Internacional (CPJI).

Já na década de 1960, mais especificamente em 1963, a Organização para a Cooperação e Desenvolvimento econômico (OCDE), deu continuidade aos estudos iniciados pela Liga das Nações, traçando seu próprio modelo de convenção para evitar a dupla tributação internacional. E, assim, se desenvolveu o Modelo de Convenção Fiscal de Rendimento e Patrimônio, revista em 1977 e comumente chamada Convenção-Modelo da OCDE, diretriz essencial no estabelecimento de políticas fiscais internacionais e que serve como paradigma às convenções tributárias internacionais ao redor do mundo.

As normas previstas nas convenções internacionais em matéria tributária devem ser interpretadas em consonância com as regras de Direito Internacional Público, quais sejam o art. 31 e 32 da Convenção de Viena

17 LIMA, Juciléia. Arbitragem tributária internacional e o discurso sul-americano da 'renúncia à soberania fiscal'. Revista Direito Tributário Atual, São Paulo, v. 33, p. 150, 2015.

18 SANTIAGO, Igor Mauler. Direito tributário internacional: métodos de solução de conflitos. São Paulo: Quartier Latin, 2006. p. 75. 
sobre o Direito dos Tratados de 1969, pelo que a interpretação deve envolver não apenas o texto do tratado em si (incluídos o preâmbulo e anexos), mas também o seu contexto. Isto significa que serão levados em consideração também os acordos já celebrados entre as partes, os instrumentos multilaterais anteriormente relacionados com o tratado, o acordo entre as partes que se dê posteriormente, as práticas ulteriores que demonstrem o consenso entre as partes, além das regras de Direito Internacional que sejam aplicáveis. Ademais, a interpretação dos tratados para se evitar a bitributação também deve levar em consideração o seu objetivo, qual seja evitar a dupla tributação internacional e a evasão fiscal, garantir tratamento não discriminatório às partes e harmonizar os sistemas tributários internos ${ }^{19}$.

Nesse sentido, quando há a interpretação divergente das normas vinculantes das convenções, isto poderá acarretar na dupla tributação internacional. Segundo Igor Santiago, os conflitos interpretativos dos tratados de dupla tributação internacional se dão em razão de algumas motivações específicas, como: (i) polissemia das formulações jurídicas e interação de ordenamentos jurídicos distintos; (ii) vaguidade dos critérios hermenêuticos da Convenção de Viena (CVDT/1969); (iii) remissão que as convenções fazem ao direito doméstico dos países, que muda ao longo do tempo; (iv) distorção do sentido dos tratados pelos órgãos jurisdicionais internos em prol dos respectivos Estados ${ }^{20}$. Os pontos sensíveis que mais suscitam controvérsia referem-se à aplicação do preço de transferência e atribuição de lucros a estabelecimentos permanentes ${ }^{21}$.

Ocorre que, em ultima ratio, os conflitos de interpretação podem levar até mesmo a situações drásticas, como a denúncia da convenção. Foi o que aconteceu com a convenção entre Brasil e Alemanha, que por divergências interpretativas, principalmente pela intepretação brasileira, acerca do art. $7^{\circ}$, que trata do lucro das empresas e das diferenças quanto às normas sobre preço de transferência, foi denunciada após 30 anos de

19 OKUMA, Alessandra. As convenções para evitar dupla tributação e elisão fiscal e os meios de solução de controvérsias. In: TÔRRES, Heleno Taveira. Direito tributário internacional aplicado. São Paulo: Quartier Latin, 2007. v. 4. p. 412.

20 SANTIAGO, Igor Mauler. Direito tributário internacional: métodos de solução de conflitos. São Paulo: Quartier Latin, 2006. p. 79.

21 OKUMA, Alessandra. As Convenções para evitar dupla tributação e elisão fiscal e os meios de solução de controvérsias. In: TÔRRES, Heleno Taveira. Direito tributário internacional aplicado. São Paulo: Quartier Latin, 2007. v. 4. p. 412. vigência ${ }^{22}$.

Nesse diapasão, verificadas as controvérsias citadas, de acordo com o previsto no art. 25 da Convenção Modelo da OCDE, aplicam-se os mecanismos para solução de conflitos de bitributação internacional, os quais serão expostos a seguir.

\subsection{Métodos de Solução de Controvérsias no Direito Tributário Internacional}

Quando a tributação se dá em desacordo com a Convenção, resultando em dupla tributação e em desvantagem aos contribuintes, estes são obrigados a litigar em cada Estado e isso envolve todas as desvantagens e as incertezas que tal situação acarreta. Pensando nisso, o art. 25 da Convenção Modelo da OCDE foi desenvolvido para trazer para a seara internacional a solução das controvérsias. Este artigo estabelece os métodos de solução de conflitos em convenções sobre dupla tributação internacional. São eles: (a) Procedimento Amigável e (b) Arbitragem.

a) Procedimento Amigável

$\mathrm{O}$ art. 25, parágrafo $1^{\circ}$ da Convenção Modelo da OCDE disponibiliza aos contribuintes afetados, sem privá-los dos meios processuais comuns disponíveis, a instauração do denominado procedimento amigável. Este possui como escopo, principalmente, a harmonização interpretativa do instrumento convencional por meio de análise dos pontos de discordância pelas autoridades administrativas dos Estados Partes das convenções. Esse procedimento pode levar, até mesmo, à facilitação da renegociação das cláusulas da convenção pelas partes.

Dentre as características gerais do procedimento amigável, destaca-se o seu caráter autônomo, visto que não depende do esgotamento dos procedimentos administrativos ou judiciais internos previstos na legislação doméstica dos Estados, e preventivo, pois além de objetivar cessar os efeitos de uma dupla tributação, pode se basear também na simples possibilidade de dupla tributaçã $\mathrm{O}^{23}$. O procedimento amigável é aplicável, somente,

22 ROTHMANN, Gerd Willi. A denúncia do acordo de bitributação Brasil-Alemanha e suas consequências. In: ROCHA, Valdir de Oliveira. Grandes questões de direito tributário. São Paulo: Dialética, 2005. v. 9.

23 XAVIER, Alberto. Direito tributário internacional do Brasil. 8. ed. Rio de Janeiro: Forense, 2015. 
para solucionar questões relativas à violação das normas previstas na convenção sobre bitributação internacional, o que significa que o procedimento servirá para adequar a tributação à convenção e não aos sistemas jurídicos internos dos Estados contratantes.

Ademais, importante salientar a característica da informalidade do procedimento amigável, pois as partes podem comunicar-se, diretamente, entre si, sem a necessidade de recorrer à via diplomática, além da inexistência de prazos ou formalidades preestabelecidas, ficando à critério das partes a criação de uma comissão composta por representantes das partes de modo a permitir, por exemplo, a troca de impressões orais.

O pedido para instauração do procedimento deve ser proposto em três anos a partir da notificação da dupla tributação contrária à convenção e o resultado do procedimento amigável não é obrigatório, pois trata-se de um pactum in contrahendo, ou seja, há a obrigação de meio e não de resultado, haja vista que as partes negociam, porém, não são obrigadas a atingirem um acordo.

Em particular para o presente estudo, ressalta-se que, segundo o art. 25 da Convenção Modelo da OCDE, esse procedimento é realizado entre as autoridades competentes dos Estados partes da convenção, ou seja, o contribuinte não é legitimado a atuar no procedimento amigável. Caberá a ele, apenas, atuar na primeira etapa do procedimento amigável, qual seja o oferecimento da reclamação para a autoridade competente do Estado em que é residente ou nacional ${ }^{24}$. Entretanto, o contribuinte deverá "aguardar a prática de atos pelos agentes fiscais do Estado contratante, que justifiquem o risco de que ele venha a sofrer tributação em desconformidade com a Convenção" "25. O ato poderá consistir tanto em normas infralegais, decisões administrativas ou de qualquer natureza, quanto em atos preparatórios do lançamento (notificações) ou lavraturas do auto de infração para a cobrança do tributo. A segunda etapa trata-se da ação da autoridade competente, que deverá propor o procedimento amigável e esforçar-se ("endeavour") reciprocamente por meio de consultas, também por meio de

24 O contribuinte atua mesmo na primeira etapa, apesar de, na etapa seguinte, manter o seu direito de ser ouvido (seja oralmente ou por escrito, diretamente ou por representante), direito de ser assistido por conselho técnico e direito de acesso ao dossier.

25 OKUMA, Alessandra. As convenções para evitar dupla tributação e elisão fiscal e os meios de solução de controvérsias. In: TÔRRES, Heleno Taveira. Direito tributário internacional aplicado. São Paulo: Quartier Latin, 2007. v. 4. p. 423. comissões técnicas, coma finalidade de se alcançar um acordo mútuo de modo a evitar a dupla tributação.

b) Arbitragem

Em 2007, o Comitê de Assuntos Fiscais da OCDE reconheceu a necessidade de alteração da Convenção Modelo, tendo sido incluído, na versão revisada de 2008, o parágrafo $5^{\circ}$ ao art. 25 , que introduz o procedimento arbitral. Salienta-se que este funcionaria subsidiariamente ao procedimento amigável, sendo "não um meio de resolução de questões de interpretação de tratados, mas parte integrante do procedimento amigável. São, portanto, institutos complementares a um único mecanismo de solução de conflitos"26.

De forma específica, o parágrafo $5^{\circ}$ prevê que, frustrado o procedimento amigável, em no máximo 2 anos da apresentação do caso à autoridade competente do outro Estado contratante, poderá ser acionada a arbitragem ${ }^{27}$. Ainda, segundo os Comentários da OCDE ao art. 25 , parágrafo 10 , os temas abordados no procedimento amigável não se restringem a ele, podendo estes, também, serem discutidos no procedimento arbitral, ou seja, não se levantam questões apenas de dupla tributação jurídica, mas também dupla tributação econômica, assim como é possível nos procedimentos amigáveis ${ }^{28}$.

Contudo, o início da arbitragem não é decorrência automática do procedimento amigável. O contribuinte inconformado com o fracasso do procedimento amigável, acionará a arbitragem, de forma semelhante àquela feita no procedimento amigável. Ou seja, apesar de ser o principal afetado pela má interpretação ou mau cumprimento do acordo, o contribuinte continua não tendo legitimidade subjetiva, tendo de recorrer ao seu Estado de residência ou nacionalidade para que abrace sua reclamação e instaure o procedimento arbitral, uma vez frustrado o procedimento amigável ${ }^{29}$.

Entretanto, apesar de não ser suficiente a ponto de

26 SCHOUERI, Luís Eduardo. Arbitragem no direito tributário internacional. Revista Direito Tributário Atual, São Paulo, v. 23, p. 302320, 2009.

27 Ainda, destaca-se que, apesar de já prever o procedimento amigável, discute-se a inclusão na Convenção Modelo da ONU da inclusão da cláusula arbitral.

28 SCHOUERI, Luís Eduardo. Arbitragem no direito tributário internacional. Revista Direito Tributário Atual, São Paulo, v. 23, p. $302-$ 320, 2009. p. 307; PIT, H. M. Arbitration under the OECD Model Convention: Follow-up under double tax conventions: an evaluation. 42 Intertax, n. 6-7, p. 445-469, 2014.

29 Ressalta-se que, existindo decisões administrativas ou judiciais em qualquer um dos Estados, o procedimento arbitral cessará. 
permitir que o contribuinte acesse diretamente o mecanismo arbitral, a OCDE estabeleceu que o contribuinte poderá apresentar por escrito a sua posição aos árbitros, igualmente ao que já ocorria no procedimento amigável, porém, poderá efetuar sustentação oral, todavia, sob a condição de concedida permissão dos árbitros. Ora, o fato de ter de passar pelo crivo do Estado para que primeiro se inicie o procedimento arbitral e, depois dos árbitros para fazerem sua defesa oral, já denota a dupla admissibilidade pela qual deve passar o contribuinte e, o que se revela como sutil possibilidade pode, a depender da análise do árbitro, tratar-se de mera ilusão, voltando-se à condição inicial.

De outro lado, explica Igor Mauler Santiago que se exige o consentimento do contribuinte para a instauração da arbitragem, impondo-lhe, ainda, declarar se aceita o laudo como vinculante. Nesse diapasão, segundo afirma o autor, "embora não tenha poderes para provocar diretamente a instauração da instância, pode o particular, ao contrário, impedi-la, ainda, que seja pouco provável que isso corresponda ao seu interesse, já que a tributação ofensiva permanecerá irremediavelmente sem solução" ${ }^{30}$.

$\mathrm{Na}$ Convenção Modelo da OCDE, as disposições sobre o procedimento arbitral são vagas, não havendo estabelecimento de prazos, rito do procedimento, escolha e número dos árbitros ou documentação necessária para o contribuinte.

Ainda são poucos os acordos que preveem que a sentença arbitral será vinculante, mesmo porque a maioria desses acordos antecede a reforma do art. 25 e o acréscimo do parágrafo $5^{\circ}$. Outrossim, ainda que a convenção disponha sobre o caráter vinculante da decisão, esta não o seria para o contribuinte, a quem é facultado escolher se aceita ou não o resultado do procedimento, pelo que se concorda com o posicionamento de Luís Eduardo Schoueri, ao afirmar que isto enfraquece o caráter vinculante da arbitragem ${ }^{31}$.

A sentença arbitral será final e as autoridades competentes deverão implementar o laudo no prazo de 6 meses a contar de sua comunicação, sendo que o cumprimento da decisão não autoriza o Estado Contratan-

30 SANTIAGO, Igor Mauler. Direito tributário internacional: métodos de solução de conflitos. São Paulo: Quartier Latin, 2006. p. 131. 31 PIT, H. M. Arbitration under the OECD model convention: follow-up under double tax conventions: an evaluation. 42 Intertax, n. 6-7, p. 445-469, 2014. p. 308. te vencedor a buscar a execução, iniciando apenas um novo contencioso internacional, que deve ser solucionado em consonância com o Direito Internacional. Desse modo, os julgadores limitar-se-ão ao exame do descumprimento da decisão proferida, não havendo reapreciação do mérito (excepcionalmente em casos de suscitação de nulidade da primeira decisão) ${ }^{32}$.

\section{4+ SOLUÇÃO DE CONTROVÉRSIAS SOBRE INVESTIMENTOS}

Após a Segunda Guerra Mundial, diversos fenômenos jurídicos foram observados na esfera internacional. No que se refere à seara do Direito Internacional dos Investimentos, desenvolveu-se a arbitragem investidor-Estado (ou mista), a qual possibilitou o acesso direto do investidor estrangeiro aos tribunais arbitrais internacionais. Isto se mostrou extremamente relevante, ao passo que com o processo de descolonização afro-asiática, uma série de reações do Terceiro Mundo contra o capital estrangeiro tomou conta do cenário internacional. Diversos episódios de discriminações e interferências efetuadas na propriedade privada dos investidores (nacionalizações e expropriações) marcaram o período das décadas de 1960-1970, o que gerou enorme instabilidade e insegurança na ordem global.

As cortes nacionais dos Estados, em particular as dos países em desenvolvimento, que eram vistas como as jurisdições tradicionais competentes para tratarem dos litígios entre investidores e Estados, no entanto, demonstraram-se aos poucos como frágeis e passíveis de influência do próprio Estado. Nessa toada, coube ao Direito Internacional o condão de trazer maior estabilidade para as relações entre os atores internacionais, por meio da criação de um arcabouço jurídico e institucional adequado e que gerasse maior segurança jurídica.

Dentre os meios jurisdicionais institucionais para a solução de controvérsias sobre investimentos, o International Centre for Settlement of Investment Disputes (ICSID) é, sem dúvida, o mais notável ${ }^{33}$, por esse motivo, optou-

32 KREPEL, Marina Meirelles Sobreira. Solucão de controvérsias nas convenções internacionais contra dupla tributação. 2014. 221 f. Dissertação (Mestrado) - Faculdade de Direito, Universidade de São Paulo, São Paulo, 2015.

33 Entretanto, esta instituição não é a única apta a solucionar litígios desta natureza, até mesmo porque nem todos os Estados fazem parte da Convenção de Washington. Outras regras inicialmente 
-se por fazer um recorte para ilustrar a arbitragem de investimentos por meio da explanação do ICSID, haja vista que a evolução dos dois se dá de forma deveras simultânea. O ICSID foi criado no contexto para estabilizar as relações entre investidores e Estados por meio a difusão e aplicação da arbitragem investidor-Estado. Segundo o diplomata Celso de Tarso Pereira, "disposições fiscais e financeiras de caráter discriminatório formavam o contexto propício para a criação de um mecanismo que favorecesse o ambiente para investimentos internacionais" ${ }^{34}$. Assim, por intermédio da Convenção sobre Resolução de Conflitos relativos a Investimentos entre Estados e Nacionais de outros Estados ou, simplesmente, Convenção de Washington de 1965, foi criado o International Centre for Settlement of Investment Disputes (ICSID), integrante do Grupo Banco Mundial, ao lado de outras quatro organizações ${ }^{35}$. O ICSID nasceu com a finalidade de facilitar a resolução de conflitos sobre investimentos estrangeiros entre Estados e partes privadas investidoras ${ }^{36}$, de modo a favorecer um ambiente de confiança mútua entre investidores e Estados nacionais e de forma a promover o fluxo de capitais para países em desenvolvimento em termos e condições razoáveis.

A Convenção de Washington estabelece que o ICSID oferecerá mecanismos apropriados tanto de conciliação, quanto de arbitragem e, ainda disporá do mecanismo complementar ${ }^{37}$. Ao Centro caberá, apenas, administrar esses procedimentos, fornecendo um arcabouço jurídico e administrativo para as arbitragens ad

instituídas para arbitragens comerciais internacionais não excluem de sua jurisdição a arbitragem de investimentos, como no caso das Regras de Arbitragem da UNCITRAL de 1976, das Regras de Arbitragem da Câmara de Comércio Internacional (CCI) e as da Câmara de Comércio de Estocolmo (CCE).

34 PEREIRA, Celso de Tarso. O Centro Internacional para a Resolução de Conflitos sobre Investimentos (CIRDI-ICSID). Revista de Informação Legislativa, Brasília, ano 35, n. 40, p. 87-93, out./dez. 1998. p. 88.

35 O Grupo Banco Mundial é composto por: (i) Banco Internacional para Reconstrução e Desenvolvimento (BIRD); (ii) Associação Internacional do Desenvolvimento (AID); (iii) Sociedade Financeira Internacional (SFI); (iv) Agência Multilateral de Garantia de Investimentos (MIGA) e pelo Centro Internacional para Arbitragem de Disputas sobre Investimentos (ICSID).

36 LOWENFELD, Andreas F. International economic law. 2. ed. Oxford: Oxford University, 2008. p. 536-537.

37 Por meio deste mecanismo, certos procedimentos entre Estados e nacionais de outros Estados não-contratantes do Centro poderão ser administrados, principalmente, caso uma das partes não se trate de Estado Contratante ou de nacional de um Estado Contratante e vise o acesso ao Centro ou, em categoria adicional, se a controvérsia não surgir diretamente de um investimento. hoc sobre a matéria investimentos.

Faz-se necessário destacar que o propósito do Banco Mundial era instituir um mecanismo pacífico de solução de controvérsias pela via judicial neutra. Neste poderiam configurar nos polos da disputa não somente Estados, mas também, de outro lado, as partes privadas investidoras. Assim, salienta-se que uma das inovações da Convenção foi relevar a capacidade aos entes privados de integrar uma relação jurídica ao lado dos Estados receptores de investimentos.

Desse modo, reconhece-se que a Convenção de Washington permite que as disputas sejam iniciadas por investidores privados e por Estados nacionais, desde que haja consentimento das partes autorizando expressamente o estabelecimento dos mecanismos arbitrais de solução de controvérsias para um conjunto determinado ou determinável de matérias ${ }^{38}$. Logo, ao ratificar a Convenção de Washington a jurisdição do Centro é reconhecida pelo Estado, entretanto, isso não obriga as partes a se submeterem à arbitragem de investimentos do ICSID. Ocorre que é preciso um duplo consentimento, e que as partes também consintam com a submissão da controvérsia ao ICSID, por escrito, não podendo os Estados ir além do que foi autorizado. ${ }^{39} \mathrm{O}$ consentimento expresso dos Estados ocorre nas seguintes hipóteses não taxativas: (i) por cláusula compromissória incorporada em um contrato entre as partes, estabelecendo que a resolução de eventuais litígios se dará sob a jurisdição do ICSID; (ii) por compromisso arbitral (compromis), para um litígio já existente; (iii) por previsão em legislação nacional do Estado receptor de investimentos, como no caso de previsão em sua legislação interna sobre investimento ${ }^{40}$ - e (iv) por meio de um acordo de promoção e proteção recíproca de investimentos, por meio de cláusulas de resolução de conflitos que preveem o compromisso de utilização da jurisdição do ICSID, como se fosse uma oferta pública de arbitragem durante o período de vigência do tratado. Os investidores, por sua vez, também, poderão dar seu consentimento mediante cláusula compromissória, compromisso arbitral e simples início do procedimento ${ }^{41}$.

38 JUILLARD, Patrick. L'évolution des sources du droit des investissements. Recueil des cours, Leiden, p. 9-216, 1994. p. 99.

39 COSTA, José Augusto Fontoura. Direito internacional do investimento estrangeiro. Curitiba: Juruá, 2010. p. 215.

40 CARREAU, Dominique; JUILLARD, Patrick. Droit international économique. 5. ed. Paris: Dalloz, 2013. p. 585.

41 CARREAU, Dominique; JUILLARD, Patrick. Droit international économique. 5. ed. Paris: Dalloz, 2013. p. 582-583. 
Consentindo à jurisdição, esse consentimento não pode ser revogado unilateralmente, mesmo que haja tentativa de terminar o contrato que possua cláusula de resoluções de controvérsias ICSID. Ademais, a revogação da legislação nacional que contenha o consentimento não poderá afetar a jurisdição do ICSID, desde que a oferta tenha sido aceita enquanto a legislação ainda estivesse em vigor.

O art. 26 da Convenção de Washington estabelece que dado o consentimento das partes para a arbitragem sob a égide do Centro, exceto disposição em contrário, exclui-se qualquer outro remédio jurisdicional. O Estado demandado tampouco poderá contestar a jurisdição do tribunal arbitral com fulcro na ausência de esgotamento prévio dos recursos internos para acessar o tribunal, porém, poderá requerer esse esgotamento como condição para o consenso à arbitragem, apesar de ser uma reserva rara nos acordos de investimento e encontrada com mais frequência em acordos de investimento mais antigos ${ }^{42}$.

No ICSID, a arbitragem de investimentos inicia-se com a requisição por escrito de arbitragem pela parte demandante (o investidor, que é o mais comum, ou o Estado receptor de investimentos). Esta deverá conter, além da identificação das partes, também o consentimento escrito e será encaminhada ao Secretário-Geral, que a aprovará e encaminhará cópia à outra parte.

Instaurado o tribunal arbitral, este será composto por árbitro singular ou número ímpar de árbitros. Não havendo indicação do número de árbitros, este será de três. Cada parte indicará um deles e o terceiro, futuro presidente do tribunal, será indicado em comum acordo entre as partes. Caso os árbitros não tenham sido indicados e o tribunal não tenha sido constituído em um prazo de 90 dias, o art. 38 da Convenção de Washington estabelece que o Secretário-Geral poderá indicá-lo (s), contudo, limitando-se a não ser de nacionalidade de qualquer das partes e devendo estar presentes na lista institucional de árbitros. ${ }^{43}$

Ressalta-se que a arbitragem de investimentos e o ICSID ganharam maior dinamicidade apenas nos anos 1990, com o fim da União Soviética. A partir de então, se tornou o principal foro para a resolução de disputas

42 DOLZER, Rudolf; SCHREUER, Christoph. Principles of international investment law. Oxford: Oxford University, 2008. p. 249.

43 COSTA, José Augusto Fontoura. Direito internacional do investimento estrangeiro. Curitiba: Juruá, 2010. p. 219. sobre investimentos, alcançando a marca, em 2014, de $497 \operatorname{casos}^{44}$. Contudo, nos anos 2000, muitos países foram demandados de forma intensa no ICSID. A Argentina - país mais demandado do Centro - foi acionada em 51 casos e desses, 19 estão em andamento, 9 são condenações, 4 são casos em que a reclamação dos investidores não procedeu e 19 são casos encerrados por descontinuidade do processo, visto que os investidores retiraram os pedidos ou houve acordo entre as partes. Por esse motivo, a Argentina tem tentado anular as sentenças arbitrais do ICSID, recusando-se a cumpri-las por falta de homologação perante as cortes internas, justificando que essas decisões somente poderiam ser executadas se iniciados procedimentos em seus tribunais ${ }^{45}$.

Somado a isso, alguns países latino-americanos retiraram-se do ICSID e denunciaram seus acordos de investimento, como Bolívia (2007), Equador (2009) e Venezuela (2012). Alegaram que estes violavam suas Constituições nacionais, as quais passaram por alterações recentes dos governos recém-assumidos à época da alteração. Para esses países, retomou-se a premissa de que as disputas concernentes a investimento devem manter-se no âmbito dos tribunais internos, afastando os foros internacionais e a arbitragem para a resolução de litígios sobre investimentos. Isso, pois, esse sistema possibilitaria a ingerência de um sistema internacional que privilegia o investidor e afastaria os interesses nacionais desses Estados. Observa-se que esses países, também, têm sido demandados perante o ICSID $^{46}$.

Apesar das críticas em função de sua transparência e imparcialidade, o ICSID continua sendo o principal foro para a solução de controvérsias sobre investimentos. Seu corpo institucional qualificado e a garantia de legitimidade processual ativa tanto para Estados, quanto para entidades privadas, sem depender do consentimento de suas nações, faz com que os investidores optem por ele, afinal, com isso não precisam convencer o Es-

44 INTERNATIONAL CENTRE FOR SETTLEMENT OF INVESTMENT DISPUTES. ICSID Caseload-Statistics (Issued 20151). 2015. Disponível em: <https://icsid.worldbank.org/apps/ICSIDWEB/resources/Documents/ICSID $\% 20$ Web $\% 20$ Stats $\% 20$ 2015-1\%20(English)\%20(2)_Redacted.pdf>.

45 Ressalta-se que muitos dos casos argentinos estão ligados às medidas cambiais adotadas pela argentina durante a crise econômica do início dos anos 2000.

46 COSTA, José Augusto Fontoura. Proteção internacional do investimento estrangeiro no Mercosul. Florianópolis: GEDAI, 2012. p. 12. ALVAREZ, José E. The return of the State. Minnesota Journal of International Law, Minneapolis, v. 20, n. 2, p. 223-264, 2011. p. 239. 
tado a encampar a sua demanda para que então siga perante o tribunal arbitral.

As demandas no Centro iniciaram-se de forma tímida, tendo evoluído mais a partir dos anos 2000. Até o momento, atingiu seu auge em 2012, com 50 casos e, em 2014, chegou a um total, desde sua criação, de 497, envolvendo tanto a Convenção de Washington, quanto o Mecanismo Complementar. Desses casos, a maioria é de arbitragens ICSID (442 casos), seguidos por 46 arbitragens via Mecanismo Complementar, 7 casos de conciliação pela Convenção de Washington e 2 casos de conciliação pelo Mecanismo Complementar.

\section{BRASIL E SUA TRADIÇÃo DE RESISTÊNCIA À ARBITRAGEM TRIBUTÁRIA E DE INVESTIMENTOS}

É possível afirmar que o Brasil encontra resistência na adoção da arbitragem tanto em matéria tributária internacional quanto na arbitragem envolvendo investidores e entes soberanos. Desse modo, passa-se a expor as motivações para tanto e, por fim, serão expostas algumas críticas a respeito, tentando unir as duas vertentes expostas de forma sistemática.

\subsection{A Resistência Brasileira à Arbitragem de Investimentos}

Ressalta-se que os instrumentos basilares do Direito Internacional dos Investimentos consistem nos acordos de promoção e proteção de investimento e na arbitragem de investimentos. Como desenvolvido anteriormente, no início dos anos 1960, com a Convenção de Washington de 1965, foi criado o ICSID. O Centro institucionalizou o mecanismo da arbitragem investidor-Estado para a solução de controvérsias entre Estados e entidades privadas. Diante isso, o Brasil manifestou-se sobre a adesão ou rejeição a esse novo sistema.

De acordo com parecer do Consultor Jurídico do Ministério das Relações Exteriores, Augusto de Rezende Rocha, de 20 de agosto de 1964, o Brasil adotou posicionamento contrário à adesão ao sistema ICSID. Os principais motivos foram que diante da existência de órgãos internacionais, como a Organização das Nações Unidas (ONU), o Banco Mundial não seria o organismo mais adequado para institucionalizar o procedimento arbitral para resolver litígios entre Estados e investido- res "supostamente desprotegidos":

[...] não é crível que qualquer Estado normalmente organizado - isto é, de acordo com o constitucionalismo propagado e fortalecido a partir do sec. XX - apresentando instituições asseguradoras de uma ordem jurídica primária, concorde de boa mente em sub-rogar funções públicas essenciais a um tribunal internacional, que na sua organização e funcionamento será passível de sofrer influências prejudiciais à própria soberania desse Estado $[\ldots]^{47}$.

Segundo o parecer "nunca o Governo brasileiro, em qualquer época, deixou de acolher, diplomática ou judicialmente, as reivindicações de meritorious cases de estrangeiros que lhe fossem apresentadas" ${ }^{\text {"48 }}$. Esta submissão ao Centro não traria maiores vantagens "a instrumentalidade judiciária de qualquer país”49. O Consultor complementa que os mecanismos arbitrais e sua disseminação independeriam de institucionalização, podendo os laudos arbitrais, quando não sustentados por princípios jurídicos universais ${ }^{50}$, concorrerem para a desconfiança quanto às imunidades dos árbitros às "injunções políticas ou econômicas" ${ }^{51}$. Por fim, o argumento, também, atende a um viés ideológico de que esta seria a "consagração do imperialismo econômico e financeiro, ainda que disfarçada" 52 , já que "consagra e quase institucionaliza o estado de tensão, tão difícil de erradicar e, relações políticas internacionais, existentes entre as economias dominantes e as econômicas dominadas" ${ }^{\prime 53}$.

Pode-se vislumbrar desse trecho que, pela ótica brasileira a introdução desses tratados no ordenamento

47 ROCHA, Augusto de Rezende. Parecer DAJ/138: criação de órgão de arbitragem internacional, BIRD. Washington: BIRD, 1964. item 17 , II.

48 ROCHA, Augusto de Rezende. Parecer DAJ/138: criação de órgão de arbitragem internacional, BIRD. Washington: BIRD, 1964. item 16.

49 ROCHA, Augusto de Rezende. Parecer DAJ/138: criação de órgão de arbitragem internacional, BIRD. Washington: BIRD, 1964. item 17 , II.

50 XAVIER JÚNIOR, Ely Caetano. Direito internacional dos investimentos e o Brasil: uma perspectiva a partir do padrão de tratamento justo e equitativo. 2014. 279 f. Dissertação (Mestrado) - Faculdade de Direito, Universidade Estadual do Rio de Janeiro, Rio de Janeiro, 2014. p.109.

51 ROCHA, Augusto de Rezende. Parecer DAJ/138: criação de órgão de arbitragem internacional, BIRD. Washington: BIRD, 1964. item 17, IV.

52 ROCHA, Augusto de Rezende. Parecer DAJ/138: criação de órgão de arbitragem internacional, BIRD. Washington: BIRD, 1964. item 17.I.

53 ROCHA, Augusto de Rezende. Parecer DAJ/138: criação de órgão de arbitragem internacional, BIRD. Washington: BIRD, 1964. item 18. 
jurídico nacional poderia limitar "a capacidade dos Estados de exercerem efetivamente tal disciplinamento" "54, e que poderiam surgir, ainda, contradições entre o objetivo das legislações internas e a finalidade dos acordos de investimento e, consequentemente, a arbitragem investidor-Estado.

Quanto aos acordos de investimento, o Brasil já demonstrou, na década de 1990, intenção de vincular-se a eles. Entretanto, estes não entraram em vigor por resistências parlamentares, dentre elas, diretamente conectada, destaca-se a oposição à arbitragem de investimentos. $\mathrm{O}$ argumento utilizado seria o de que representa uma violação ao princípio do esgotamento dos recursos internos antes que se recorra à jurisdição internacional. Além disso, a arbitragem de investimentos colocaria o Estado brasileiro em patamar de igualdade com o investidor diante de um tribunal arbitral - duas entidades distintas por natureza - o que violaria sua soberania ${ }^{55}$. Acrescenta-se a isso, a preocupação de que o sistema arbitral afastaria a competência do judiciário brasileiro a apreciação do Poder Judiciário lesão ou ameaça a direito, prevista no art. $5^{\circ}$, XXXV da Constituição Federal brasileira. Ademais, afirmava-se, também, que os textos discriminavam o investidor nacional, haja vista que privilegiaria o investidor estrangeiro em detrimento daquele, o qual não teria acesso ao mesmo tipo de proteção acordada, o que distorceria as regras de concorrência e de livre mercado ${ }^{56}$.

Ocorre que pontos de resistência como a de renúncia à soberania nacional torna-se ultrapassada, ao passo que ao se vincular ao tratado, o Estado o faz por expressão de sua autonomia da vontade, o que, desse modo,

54 BRASIL. Parecer da Comissão de Constituição e Justiça e de Redação, de 21 de julho de 1997, ao Projeto de Decreto Legislativo n. 395 de 2000. Diário da Câmara dos Deputados, Brasília, 20 de janeiro de 2000 . p. 9.

55 AZEVEDO, Débora Bithiah de. O capital estrangeiro terá regras estáveis por 25 anos? Os acordos de promoção e proteção de investimentos em tramitação no Congresso Nacional. Cadernos ASLEGIS, Brasília, v. 5, n. 4, p. 21-30, maio/ago. 2001. Disponível em: <http://bd.camara.gov.br/bd/handle/bdcamara/11190>. Acesso em: 2 jun. 2016. p. 27; AZEVEDO, Débora Bithiah de. Os acordos para a promoção e a proteção recíproca de investimentos assinados pelo Brasil. Brasília: Câmara dos Deputados, 2001. Disponível em: <http://bd.camara.gov.br/bd/bitstream/handle/bdcamara/2542/ acordos_promocao_azevedo.pdf?sequence $=1>$. Acesso em: 2 maio 2016.

56 BRASIL. Parecer da Comissão de Relações Exteriores e Defesa Nacional [ao Projeto de Decreto Legislativo nº 367 de 1996]. Exposição do Deputado Luiz Gushiken. Diário da Câmara dos Deputados, Brasília, 4 de maio de 2000. em vez de subordinação, configura-se como exercício de sua própria soberania estatal, que poderá escolher quando vincular sua jurisdição.

No entanto, com os Acordos de Cooperação e Facilitação de Investimentos (ACFIs) assinados em 2015, essa mesma objeção retorna. O Brasil passa, atualmente, por um período de gradual transição de seu perfil econômico internacional, de apenas receptor de investimentos para, também, investidor. Isso suscitou uma mudança de posição do governo brasileiro em direção à aderência aos acordos de promoção e proteção de investimentos, para que se possa salvaguardar os interesses das transnacionais brasileiras no exterior, haja vista que estes nem sempre foram bem recebidos no exterior, conforme se vislumbra nos paradigmáticos casos da nacionalização dos ativos da Petrobrás na Bolívia em 2006 e da expulsão da Odebrecht do Equador em 2008, em que empresas brasileiras perderam seus ativos sem qualquer tipo de compensação.

Em 2015, o Brasil iniciou a assinatura de um novo modelo de acordo de investimentos com países da África e América Latina ${ }^{57}$, delineando nesse instrumento jurídico novas estruturas que acompanham sua política para proteção e promoção de investimentos, contudo, mantendo alguns posicionamentos tradicionais ${ }^{58}$.

No que tange à solução de controvérsias, foi estabelecido um reforço na governança institucional dos acordos e a opção por mecanismos de prevenção e solução de controvérsias. De forma geral, os ACFIs preveem, no bojo do mecanismo preventivo, que cada Parte designará um Ponto Focal ou ombudsman, que terá a função de servir como um importante canal de comunicação e apoio entre investidores e o Estado receptor, uma vez que os investidores poderão recorrer a ele diretamente, como uma via oficial para tratar de questões e problemas ainda em estágio inicial.

Caso esse método preventivo não seja frutífero e a controvérsia ainda persistir, no âmbito do quadro institucional estabelecido pelos ACFIs, encontra-se prevista

57 Até o momento, já foram assinados ACFIs com Moçambique, Angola, México, Malaui, Colômbia, Chile e Peru.

58 MOROSINI, Fábio; XAVIER JÚNIOR, Ely Caetano. Regulação do investimento estrangeiro direto no Brasil: da resistência aos tratados bilaterais de investimento à emergência de um novo modelo regulatório. Revista de Direito Internacional. v. 12, n. 2, p. 23-27, 2015; MONEBHURRUN, Nitish. Crônicas do direito internacional dos investimentos. Revista de Direito Internacional, v. 12, n. 2, p. 65-76, 2014. 
a instalação de um Comitê Conjunto para a administração e gestão dos acordos e assessoramento das relações comerciais entre as partes. Este será composto por representantes governamentais de ambos os Estados Partes, que serão designados por seus respectivos governos. Dentre suas funções, destaca-se a de resolver amigavelmente quaisquer questões ou controvérsias sobre investimentos. Entretanto, ressalta-se que nesta estrutura institucional, apenas os Estados são legitimados, tendo o investidor de procurar seu Estado de origem, que deverá encampar a demanda para então acionar o Comitê.

No entanto, caso o mecanismo preventivo não alcance sucesso, resta a opção jurisdicional da arbitragem, prevista nos ACFIs. Apesar da opção pelo procedimento arbitral, esta trata-se da arbitragem entre Estados e não a arbitragem investidor-Estado.

Nota-se que, no mecanismo dos ACFIs, não é o investidor o sujeito apto a reclamar diretamente seus prejuízos perante o tribunal arbitral, porém, "qualquer das Partes", ou seja, os Estados Partes, que, após análise discricionária de conveniência para se seguir com a controvérsia. Essa previsão faz com que se observe certo ceticismo acerca da arbitragem de investimentos ${ }^{59} \mathrm{e}$, também, faz com que se lembre do tradicional método da proteção diplomática, ainda operante, contudo, com uso menos frequente, haja vista que após o surgimento da oportunidade de os próprios investidores acessarem diretamente mecanismos de solução de controvérsias para resolver suas disputas contra Estados Anfitriões, o particular optou por instaurar procedimento diretamente, sem as amarras estatais. Desse modo, por intermédio desse acordo, o investidor de qualquer das Partes volta a depender do juízo político de conveniência do Estado para que se siga com o contencioso e para que tenha seus direitos protegidos.

59 Vale destacar que, conforme bem expõe Nitish Monebhurrun, a União Europeia também passa por uma fase de ceticismo acerca da arbitragem de investimentos, diante do recente caso Vattenfall $c$. Alemanha, em que uma empresa sueca demandou o Estado alemão, tornando-o réu em razão da adoção por este de medidas regulatórias em 2011 de modo a limitar e a posteriori interditar o uso da energia nuclear. Desse modo, os Estados europeus têm passado também para a condição de réus, o que tem lhes chamado a atenção para o repensar desse sistema de solução de controvérsias. Para mais detalhes: MONEBHURRUN, Nitish. Crônicas do direito internacional dos investimentos. Revista de Direito Internacional, v. 12, n. 2, p. 12-14, 2014.

\subsection{Arbitragem de Direito Tributário Internacional no Brasil}

O Brasil nunca celebrou acordo de bitributação prevendo a arbitragem e, apesar de ter o mecanismo do procedimento amigável disposto no bojo de seus tratados, nunca utilizou deste. É reconhecido pela doutrina que o país possui resistência acerca do procedimento amigável e, por certo, também da arbitragem.

O que se alega é que, em razão do princípio da legalidade, nem mesmo o procedimento amigável teria respaldo na legislação pátria. Nesse sentido, não poderia o representante brasileiro dispor ou abrir mão de competência tributária quando da negociação do procedimento amigável com o outro Estado contratante, ainda que isto se proceda por problemas de interpretação do acordo.

Segundo Luís Eduardo Schoueri, o pano de fundo deste argumento baseia-se no "princípio da legalidade e da irrenunciabilidade do crédito tributário, de que as autoridades fiscais não podem deixar de cobrar tributo instituído em lei por conta de negociações no âmbito do procedimento amigável, sendo tal raciocínio aplicável, por analogia, à arbitragem" ${ }^{60}$.

O princípio da legalidade em matéria tributária está previsto no art. 150, inciso I da Constituição Federal e, segundo este, proíbe-se a União, Estados, Distrito Federal e Municípios de exigirem ou aumentarem tributo na ausência de lei que o estabeleça. Logo, faz-se necessária uma lei para que se exija um tributo e todos os mecanismos obrigatórios para a obrigação tributária devem estar lá, não podendo deixar para o Executivo a tarefa de completá-la ${ }^{61}$.

Traz-se à baila, também, a questão da irrenunciabilidade do crédito tributário, disposto no art. $3^{\circ}$ do Código Tributário Nacional (CTN) e que pode ser lida juntamente com o art. 142 do mesmo diploma legal. Tributo trata-se de prestação pecuniária compulsória, ou seja, instituída em lei e cobrada mediante atividade administrativa plenamente vinculada e obrigatória, sob pena de responsabilidade funcional. Assim, se a ativi-

60 SCHOUERI, Luís Eduardo. Arbitragem no Direito Tributário Internacional. Revista Direito Tributário Atual, São Paulo, v. 23, p. $302-$ 320, 2009. p. 309.

61 SCHOUERI, Luís Eduardo. Arbitragem no direito tributário internacional. Revista Direito Tributário Atual, São Paulo, v. 23, p. $302-$ 320, 2009. p. 309. 
dade tributária é vinculada, não há a opção de realizá-la por outro meio, apenas pelo descrito pelo legislador, e, por ser obrigatória, as autoridades não poderão abrir mão deste direito ${ }^{62}$.

Logo, a resistência brasileira ao procedimento amigável e à arbitragem, localiza-se no argumento de que ao negociar com outro Estado Contratante, as autoridades nacionais estariam lançando mão de tributação devida aos cofres públicos, "ainda que se reconheça que tal montante decorra de uma interpretação errônea do Fisco brasileiro a respeito de dispositivos de determinado acordo de bitributação. Em face da irrenunciabilidade do crédito tributário, tais procedimentos configurar-se-iam ilegais" "33.

Não há o que se discutir acerca da vinculação e obrigatoriedade do crédito tributário, contudo, a questão que se coloca é quando não há certeza acerca do surgimento da obrigação tributária. Ora, para a corrente que defende a natureza declaratória do lançamento do crédito tributário, a obrigação teria surgido como fato ocorrido em momento anterior e a atividade da autoridade administrativa teria o condão investigativo, pelo que se busca o real intuito, ou "a verdade material" ${ }^{64}$. Desse modo, mesmo após o lançamento, a descoberta de um erro de fato permitiria novo lançamento, se não prescrito o crédito tributário, e uma reapreciação dos fatos poderia permitir novo lançamento. Esta ótica pode ser lida em conjunto com ao art. 149, inciso VIII do CTN, uma vez que se admite a revisão do lançamento quando deva ser apreciado fato não conhecido ou não provado por ocasião do lançamento anterior. Assim, pode ser o caso de a arbitragem levarem ao lançamento ${ }^{65}$.

No que tange ao erro de direito, a legalidade se coloca como obstáculo ao não permitir que o lançamento contrarie a lei. Contudo, segundo aduz Luís Eduardo Schoueri, a lei jamais será totalmente precisa, pois "por mais que se busque clareza, o legislador não terá como

62 SCHOUERI, Luís Eduardo. Arbitragem no direito tributário internacional. Revista Direito Tributário Atual, São Paulo, v. 23, p. 302320, 2009. p. 310.

63 SCHOUERI, Luís Eduardo. Arbitragem no direito tributário internacional. Revista Direito Tributário Atual, São Paulo, v. 23, p. $302-$ 320, 2009. p. 310.

64 SCHOUERI, Luís Eduardo. arbitragem no direito tributário internacional. Revista Direito Tributário Atual, São Paulo, v. 23, p. 302320, 2009. p. 311.

65 SCHOUERI, Luís Eduardo. Arbitragem no direito tributário internacional. Revista Direito Tributário Atual, São Paulo, v. 23, p. 302320, 2009. p. 312. afastar dúvidas acerca das hipóteses previstas, cuja conceituação apenas se torna precisa em um longo processo de evolução jurisprudencial”. ${ }^{66}$ Logo, a legislação tributária se encontra dotada também de certo caráter de indeterminação. $\mathrm{O}$ autor ainda afirma que, isto faz com que se chegue a outro ponto, o de que não existe somente uma solução ou interpretação correta, pois uma mesma situação fática poderá admitir não necessariamente uma solução jurídica, mas várias, de acordo com a lei, e, dessas, também, não quer dizer que, apenas, uma seja correta.

Nesse sentido, outra questão que se coloca é a da inafastabilidade do Judiciário para, garantia estabelecida no art. $5^{\circ}$, XXXV da Constituição Federal, se analisar lesão ou ameaça de lesão e se esta seria óbice para a análise pelo árbitro. Ora, o direito de ir ao Judiciário trata-se de garantia do indivíduo e não do Estado, desse modo, o indivíduo tanto tem o direito de acionar o judiciário estatal, como também o direito de não o fazer se assim preferir e, se a própria lei estabelece a arbitragem em seu contexto, resta-se claro que não há qualquer violação ${ }^{67}$.

Ademais, o fato de haver previsão legal da arbitragem não significa que esta será afastada dos controles de legalidade, mesmo porque caberá ao legislador descrever as hipóteses de incidência do mecanismo arbitral, bem como os critérios, prazos e demais detalhes atinentes ao procedimento da arbitragem.

Soma-se a esse argumento contrário também outro, o de que tanto o procedimento amigável quanto a arbitragem não possuem legitimidade face à ausência de aprovação de seus resultados pelo Presidente da República, em afirmação do art. 84, inciso VIII da Constituição, porquanto compete privativamente ao Presidente celebrar tratados, convenções e atos internacionais, com posterior referendo exclusivo do Congresso Nacional (art. 49, inciso I da CF). Assim, segundo essa proposição, se nem o procedimento amigável e nem a arbitragem passam pelo crivo do Presidente e do Legislativo federal, estes são inconstitucionais ${ }^{68}$.

66 SCHOUERI, Luís Eduardo. Arbitragem no direito tributário internacional. Revista Direito Tributário Atual, São Paulo, v. 23, p. 302320, 2009. p. 312.

67 SCHOUERI, Luís Eduardo. Arbitragem no direito tributário internacional. Revista Direito Tributário Atual, São Paulo, v. 23, p. $302-$ 320, 2009. p. 316.

68 SCHOUERI, Luís Eduardo. Arbitragem no direito tributário internacional. Revista Direito Tributário Atual, São Paulo, v. 23, p. 302320, 2009. p. 319. 
Nesse ínterim, pode-se afirmar que os acordos para evitar a dupla tributação constituem de pronto instrumentos em que os Estados delimitam competências tributárias, renunciando em comum acordo de certas pretensões. Esse exercício já se trata de um acordo que autolimita a soberania dos Estados, fixando os limites das jurisdições dos Estados contratantes. Logo, a lei nacional e o acordo de bitributação versam sobre matérias de competências distintas e, não sei pode admitir lei que contrarie a norma internacional, que impõe limitações à jurisdição nacional. Desse modo, a convenção para evitar a dupla tributação se trata de ferramenta limitadora da soberania estatal, bem como de sua jurisdição.

Esclarecidos e rebatidos certos argumentos de oposição ligados ao direito interno brasileiro, contrários ao da arbitragem no direito tributário, com base na doutrina mais recente, parte-se de um novo pressuposto: e se a arbitragem tributária internacional no Brasil fosse aceita. Mesmo assim, qual seria o papel do contribuinte? Teria ele participação e efetividade na reivindicação de seu pleito? Nesse ponto, pode-se unir as duas abordagens discutidas no artigo em prol de uma crítica semelhante contra o posicionamento brasileiro à arbitragem envolvendo particulares e ente estatais

\subsection{Arbitragem Tributária Internacional e de Investimentos para o Brasil}

O estudo da arbitragem no Direito Tributário Internacional e no Direito Internacional dos Investimentos possui vieses distintos, mas também algumas características em comum. A primeira delas é a valorização de mecanismos pacíficos de solução de controvérsias, o que envolve métodos conciliatórios. Tanto no ICSID quanto no ACFI brasileiro e nas convenções de bitributação há a previsão de meios alternativos de solução de controvérsias e, até mesmo preventivos, para que se tente primeiro resolver a controvérsia em bases negociadoras, previsão esta contida nos acordos de investimentos por vezes como necessária antes que se acione a arbitragem. A segunda delas é que em ambos os casos a vítima que é afetada pelas circunstâncias são particulares, seja o investidor, seja o contribuinte e, de outro lado, tem-se o ente Estatal. Por fim, ambas preveem o mecanismo da arbitragem como meio jurisdicional eleito para solucionar conflitos.

Nota-se que o Brasil é resistente à arbitragem, principalmente, no que toca ao acesso dos indivíduos ao sistema arbitral internacional de investimentos. Posição que não se coaduna com os dias de hoje, muito menos com a prática arbitral comercial brasileira. Apesar de os sistemas de prevenção e solução de controvérsias presentes nos ACFIs terem sido engendrados para amparar institucionalmente os investidores, ressalta-se que estes possuem algumas características que não colaboram inteiramente para a melhor efetividade desse objetivo.

Dentre elas, destaca-se, principalmente, a limitação da legitimidade de acesso ao sistema preventivo e jurisdicional de solução de controvérsias. Ocorre que a opção escolhida pelo Brasil nos ACFIs é a da arbitragem internacional entre Estados, em que apenas estes são legitimados a submeter e prosseguir com a controvérsia no mecanismo arbitral internacional. Desse modo, assim como na proteção diplomática, o deslinde da arbitragem dependerá da "capacidade dos investidores de convencer o governo de seu país de origem de que vale a pena dispender recursos financeiros e capital político na defesa de seus interesses" ${ }^{\prime \prime 9}$, sendo o acesso da reclamação do investidor à arbitragem incerto e improvável ${ }^{70}$. Logo, por não permitir o acesso direto do investidor ao mecanismo arbitral, isto reduz a capacidade de alavancagem das negociações nas fases pré-contenciosas ${ }^{71}$. Isto, pois, não há como prever que os casos não resolvidos por meios preventivos poderão seguir à arbitragem, haja vista a dependência de o Estado achar conveniente ou não esta ação, diferentemente do acesso direto do investidor na arbitragem de investimentos que, na mesma situação, ainda se sentindo prejudicado, poderia seguir com o pleito na arbitragem diretamente, escolha que seria tomada com base na análise prévia das vantagens e desvantagens futuras do investidor com um possível resultado ao se optar pela arbitragem. Assim, prevendo-se o possível resultado, o investidor poderia escolher diretamente a conveniência da arbitragem para seu caso específico se assim o conviesse. Por isso, neste entendimento, a melhor escolha para o Brasil seria não a arbitragem entre Estados, prevista atualmente, mas sim a arbitragem de investimentos.

69 COSTA, José Augusto Fontoura. Os ACFIs e (a falta de) proteção dos investidores. Valor Econômico, Brasília, 30 de jul. 2015. Disponível em: <http://www.valor.com.br/colunistas/ Jos $\%$ C3\%A9\%20Fontoura $\% 20$ Costa $>$. Acesso em: 6 jun. 2016. 70 COSTA, José Augusto Fontoura; GABRIEL, Vivian Daniele Rocha. O Brasil, ACFIs e a arbitragem de investimentos. Revista Internacional de Arbitragem e Conciliação, Lisboa, v. 8, p. 63-81, 2015.

71 GABRIEL, Vivian Daniele Rocha. A proteção jurídica dos investimentos brasileiros no exterior. 2015. 266 f. Dissertação (Mestrado) Faculdade de Direito, Universidade de São Paulo, São Paulo, 2015. 
Infere-se, também, que o Brasil é resistente à arbitragem nas convenções de bitributação. No entanto, pelos motivos acima expostos, esta oposição não se fundamenta, pois em matéria de direito interno, a arbitragem poderia ser admitida em face de um conflito, mesmo diante da previsão da inafastabilidade de jurisdição, visto que optou pela arbitragem. Outrossim, a arbitragem, também, não se trata de obstáculo à legalidade, uma vez que a própria lei a prevê e a sentença arbitral seria mais uma dentre as decisões "corretas" existentes ${ }^{72}$.

Desse modo, a arbitragem como mecanismo de solução de controvérsias no direito tributário internacional e nas convenções brasileiras para evitar a dupla tributação seria plenamente aplicável. Suponhamos que isto se tornasse uma realidade.

Como exposto anteriormente, a arbitragem nos tratados de bitributação é subsidiariamente ligada ao procedimento amigável, tendo neste uma etapa prévia e obrigatória. Considerando-se as principais críticas ao procedimento amigável, como por exemplo a de que não se abre ao contribuinte a possibilidade de atuar nas negociações, "o que frequentemente pode levar ao desvirtuamento do escopo do processo, que não considera as situações concretas que motivaram o início da negociação" 73 , nem necessariamente o interesse do contribuinte, e a não obrigatoriedade de os Estados chegarem a um resultado dentro de um prazo definido, assim, se houver ineficácia desde procedimento, esta é explicada em razão de sua própria sistemática, que compreende a discussão entre duas autoridades tributárias de Estados distintos, acostumadas a conflitos com contribuintes, sempre procurando assegurar a arrecadação e pouco dispostas a abrir mão de sua parcela tributável.

Não havendo negociação, passa-se à arbitragem. Contudo, a arbitragem prevista nas convenções de bitributação seguem o parâmetro do procedimento amigável: não há acesso direto do contribuinte, apenas há negociação entre as entidades competentes dos Estados, apesar de poder apresentar por escrito sua posição aos árbitros e de poder realizar sustentação oral, esta última, por exemplo está condicionada à aceitação do árbitro. Em resumo, mesmo apresentando essa defesa,

72 SCHOUERI, Luís Eduardo. Arbitragem no direito tributário internacional. Revista Direito Tributário Atual, São Paulo, v. 23, p. 302320, 2009. p. 320.

73 SCHOUERI, Luís Eduardo. Arbitragem no direito tributário internacional. Revista Direito Tributário Atual, São Paulo, v. 23, p. 302320, 2009. p. 304. apenas se permitido, a negociação continua a cargo do Estado e suas autoridades fiscais, que continuará agindo nas negociações à sua conveniência e com o embasamento jurídico que melhor lhe aprouver, o qual nunca vai ser igual ao do particular lesado, que em razão de sua condição, tentará sempre perseguir seus. Desse modo, em concreto, mesmo na arbitragem, o contribuinte permanece na condição de mero expectador. Além disso, o fato de o laudo arbitral não ser vinculante também pode influenciar nas negociações, pois não há estímulo das partes em alcançar a melhor solução possível, visto que os Estados poderão adotar ou não, podendo procrastinar indefinidamente nas negociações.

Assim, seguindo o fio condutor do presente artigo, tem-se que o Brasil deveria prever em suas convenções para evitar a bitributação a arbitragem. Contudo, para que não repita a escolha dos ACFIs, deve ser previsto o acesso direto do contribuinte. Isto seria benéfico, pois, da mesma forma que a argumentação crítica em relação à arbitragem entre Estados nos tratados de investimentos, haveria maior alavancagem para a negociação em fases anteriores, haja vista que, se ambas as partes sabem o direito que paira sobre a arbitragem, fica mais fácil de as partes preverem o custo benefício de se iniciar o procedimento arbitral, logo, tendo essa previsibilidade, os dois lados já estariam preparados para a ação de ofertas de propostas e contrapropostas para se evitar que a reclamação evolua para uma situação mais onerosa que a anterior, havendo estímulo para a negociação.

Além disso, o acesso do contribuinte para defender seus próprios interesses se mostra interessante do próprio ponto de vista da arbitragem, visto que além de poder apresentar defesa escrita e oral, livremente e sem o condicionamento da aceitação do tribunal arbitral, poderá decidir a ação a ser tomada por seu próprio arbítrio, sem a dependência do Estado de residência ou de origem para agir em seu nome.

Segundo pontua Igor Santiago, já existem algumas iniciativas na arbitragem em matéria tributária internacional em que se dá maior acesso ao contribuinte, apesar de ainda limitadas. Este é o caso as convenções entre Alemanha e Franca e Alemanha e Suécia, que garante direito de o contribuinte ser amplamente ouvido (fully) heard), de protocolar petições e de apresentar requerimentos escritos e de Itália e Líbano, em que o contribuinte terá o direito de, mediante solicitação, ser ouvido 
pela corte arbitral ou ser representado perante ela ${ }^{74}$.

A última questão que se coloca é a da vinculação do laudo arbitral, pelo que se o Brasil adotasse a arbitragem conforme os moldes da Convenção Modelo da OCDE, deveria se ater à modificação quanto à execução do laudo, visto que uma decisão não obrigatória, acaba por não estimular as partes a persegui-la, avidamente, podendo postergá-la o quanto quiserem e, por óbvio, não a adotar após todo o procedimento e desgaste passado.

O fato é que o Brasil deveria deixar de lado sua resistência à arbitragem nas convenções para evitar a dupla tributação, com ressalvas e modificações quanto ao acesso do contribuinte, e à arbitragem de investimentos. Possibilitando o acesso tanto do contribuinte quanto do investidor brasileiro à arbitragem, este passará da posição de mero expectador, à espera de uma decisão por parte dos Estados, para efetivo participante na busca por seus interesses.

Ademais, soma-se a isso que, atualmente, esse posicionamento de resistência tanto para a arbitragem tributária internacional quanto para a arbitragem de investimentos torna-se estranha face à boa experiência do país no que se refere à Lei nº 9.607/96 (Lei Brasileira de Arbitragem) e à arbitragem comercial, à aceitabilidade pelo Judiciário nacional da arbitragem, à declaração do Supremo Tribunal Federal (STF) pela sua constitucionalidade e à adesão do Brasil à Convenção de Nova Iorque de 1958 em 2002, para a homologação de sentenças arbitrais estrangeiras. Portanto, esses elementos fazem com que o argumento de oposição à arbitragem internacional não mais se sustente ${ }^{75}$.

\section{Considerações finais}

Desse modo, conclui-se que o Brasil não pode ficar a parte das tendências mundiais e à globalização econômica que dinamiza as relações cada vez mais intensamente. A previsibilidade das relações jurídicas é elemento fundamental que propicia os investimentos estrangeiros,

74 SANTIAGO, Igor Mauler. Direito tributário internacional: métodos de solução de conflitos. São Paulo: Quartier Latin, 2006. p. 232. 75 TIBÚRCIO, Carmen. Arbitragem de investimento no Brasil In: RIBEIRO, Marilda Rosado de Sá (Org.) Direito internacional dos investimentos. Rio de Janeiro: Renovar, 2014. p. 233-270; TIBÚRCIO, Carmen. A arbitragem no direito brasileiro: o histórico e lei 9.307/96. Revista de Processo, São Paulo, v. 104, p.79-99, 2001. atrai empresas transnacionais, fomenta as economias e permite o crescimento econômico.

Nesse sentido, o conceito de Direito Transnacional se adequa perfeitamente ao estudo realizado, pois envolve atores internacionais que vivenciam relações além de suas fronteiras de origem, e que diante da celeuma jurídica que se coloca, não havendo respostas suficientes nos ordenamentos jurídicos estatais, deslocam eventuais litígios para âmbitos transnacionais.

Os mecanismos de solução de controvérsias, em especial a arbitragem, possibilitam ao direto segurança jurídica, elemento necessário para a estabilidade das relações sociais e econômicas. Tanto do ponto de vista do Direito Tributário Internacional quanto do Direito Internacional dos Investimentos a arbitragem se revela como instrumento eficaz para solução de conflitos, no entanto, com algumas ressalvas.

A principal delas é a de que a participação do particular deve ser legitimada, para que possa atuar diretamente no procedimento arbitral, com liberdade e sem que tenha de depender do crivo do Estado soberano para resolver sua reclamação. Nas convenções de bitributação isso se mostra delicado, ao passo que apesar de algumas evoluções no que tange à sutil atuação do contribuinte, ela depende da permissão do tribunal arbitral e, a palavra final, ainda acaba sendo do Estado. O posicionamento brasileiro nesse sentido ainda é de resistência, pois sequer prevê o mecanismo tradicional de arbitragem em suas convenções internacionais para evitar a dupla tributação.

Já no Direito dos Investimentos, o acesso do particular foi considerado uma das principais inovações do século XX em matéria de acesso à justiça internacional, que antes era adstrita aos Estados soberanos. Contudo, contrariando essa tendência está o Brasil, que finalmente quando adota um novo modelo de acordo de investimentos, elege a arbitragem de investimentos como mecanismo de solução de controvérsias o que, conforme já exposto ao longo do artigo, faz com que não se tenha a alavancagem necessária para a negociação nas etapas anteriores, nem possibilita que o próprio interessado atue, diretamente, no procedimento.

Nesta toada, conclui-se que não adianta o Brasil mudar o posicionamento sem adaptações. E estas devem vir de modo a possibilitar o acesso do particular à arbitragem nas convenções de bitributação e nos ACFIs, para que nem as negociações em fases preliminares, nem 
o procedimento arbitral se prolonguem, indefinidamente, ao crivo do interesse estatal, e que seja compatível com o melhor interesse do contribuinte e do investidor, bem como seja vinculante, haja vista que muitas vezes o Estado pode optar por evitar desgastes políticos e financeiros, o que faz com que o procedimento seja prejudicado. Logo, essa solução tornar-se-á perfeitamente uma manifestação do Direito Transnacional, dando suporte para a estabilização das relações entre os referidos agentes dinâmicos.

\section{REFERÊNCIAS BIBLIOGRÁFICAS}

ALVAREZ, José E. The return of the State. Minnesota Journal of International Law, Minneapolis, v. 20, n. 2, p. 223-264, 2011.

AZEVEDO, Débora Bithiah de. O capital estrangeiro terá regras estáveis por 25 anos? Os acordos de promoção e proteção de investimentos em tramitação no Congresso Nacional. Cadernos ASLEGIS, Brasília, v. 5, n. 4, p. 21-30, maio/ago. 2001. Disponível em: <http:// bd.camara.gov.br/bd/handle/bdcamara/11190>. Acesso em: 2 jun. 2016.

AZEVEDO, Débora Bithiah de. Os acordos para a promoção e a proteção reciproca de investimentos assinados pelo Brasil. Brasília: Câmara dos Deputados, 2001. Disponível em: <http://bd.camara.gov.br/bd/bitstream/ handle/bdcamara/2542/acordos_promocao_azevedo. pdf?sequence=1>. Acesso em: 2 maio 2016.

BRASIL. Parecer da Comissão de Constituição e Justiça e de Redação, de 21 de julho de 1997, ao Projeto de Decreto Legislativo n. 395 de 2000. Diário da Câmara dos Deputados, Brasília, 20 de janeiro de 2000.

BREMMER, Ian; KEAT, Preston. The fat tail the power of political knowledge for strategic investing. Oxford: Oxford University, 2009.

CARREAU, Dominique; JUILLARD, Patrick. Droit international économique. 5. ed. Paris: Dalloz, 2013.

COSTA, José Augusto Fontoura. A autonomia da nova lex mercatoria e a estabilização de relações comerciais internacionais. Revista do Instituto do Direito Brasileiro, v. 2, p. 4783-4810, 2013.

COSTA, José Augusto Fontoura. Direito internacional do investimento estrangeiro. Curitiba: Juruá, 2010.
COSTA, José Augusto Fontoura. Os ACFIs e (a falta de) proteção dos investidores. Valor Econômico, Brasília, 30 de jul. 2015. Disponível em: <http://www.valor. com.br/colunistas/Jos $\%$ C3\%A9\%20Fontoura $\% 20 \mathrm{Co}-$ sta $>$. Acesso em: 6 jun. 2016.

COSTA, José Augusto Fontoura. Proteção e promoção do investimento estrangeiro no Mercosul: uma ferramenta para a implementação de um bom clima de investimentos? Revista Brasileira de Política Internacional, v. 49, n. 2, p. 60-77, 2006.

COSTA, José Augusto Fontoura. Proteção internacional do investimento estrangeiro no Mercosul. Florianópolis: GEDAI, 2012.

COSTA, José Augusto Fontoura; GABRIEL, Vivian Daniele Rocha. O Brasil, ACFIs e a arbitragem de investimentos. Revista Internacional de Arbitragem e Conciliação, Lisboa, v. 8, p. 63-81, 2015.

DOLZER, Rudolf; SCHREUER, Christoph. Principles of international investment law. Oxford: Oxford University, 2008.

GABRIEL, Vivian Daniele Rocha. A proteção jurídica dos investimentos brasileiros no exterior. 2015. 266 f. Dissertação (Mestrado) - Faculdade de Direito, Universidade de São Paulo, São Paulo, 2015.

INTERNATIONAL CENTRE FOR SETTLEMENT OF INVESTMENT DISPUTES. ICSID Caseload-Statistics (Issued 2015-1). 2015. Disponível em: < https:// icsid.worldbank.org/apps/ICSIDWEB/resources / Documents/ICSID $\% 20$ Web $\% 20$ Stats $\% 202015-1 \% 20$ (English)\%20(2)_Redacted.pdf>.

JESSUP, Philip C. Direito transnacional. Rio de Janeiro: Fundo de Cultura, 1965.

JUILLARD, Patrick. L'évolution des sources du droit des investissements. Recueil des cours, Leiden, p. 9-216, 1994.

KREPEL, Marina Meirelles Sobreira. Solução de controvérsias nas convenções internacionais contra dupla tributação. 2014. 221 f. Dissertação (Mestrado). Faculdade de Direito, Universidade de São Paulo, São Paulo, 2015.

LIMA, Juciléia. Arbitragem tributária internacional e o discurso sul-americano da 'renúncia à soberania fiscal'. Revista Direito Tributário Atual, São Paulo, v. 33, 2015.

LOWENFELD, Andreas F. International economic law. 2. ed. Oxford: Oxford University, 2008. 
MONEBHURRUN, Nitish. Crônicas do direito internacional dos investimentos. Revista de Direito Internacional, v. 12, n. 2, p. 65-76, 2014.

MONEBHURRUN, Nitish. Crônicas do direito internacional dos investimentos. Revista de Direito Internacional. v. 12, n. 2, p. 12-14, 2014.

MOROSINI, Fábio; XAVIER JÚNIOR, Ely Caetano. Regulação do investimento estrangeiro direto no Brasil: da resistência aos tratados bilaterais de investimento à emergência de um novo modelo regulatório. Revista de Direito Internacional, v. 12, n. 2, p. 422-447, 2015.

OKUMA, Alessandra. As convenções para evitar dupla tributação e elisão fiscal e os meios de solução de controvérsias. In: TÔRRES, Heleno Taveira. Direito tributário internacional aplicado. São Paulo: Quartier Latin, 2007. v. 4.

ORGANISATION FOR ECONOMIC CO-OPERATION AND DEVELOPMENT. Interconnected economies: Benefiting from global value chains. OECD. 2013. Disponível em: <https://www.oecd.org/sti/ind/interconnected-economies-GVCs-synthesis.pdf $>$. Acesso em: 06 maio 2016.

PENROSE, Edith. A teoria do crescimento da firma. Campinas: Unicamp, 2006.

PEREIRA, Celso de Tarso. O Centro Internacional para a Resolução de Conflitos sobre Investimentos (CIRDI-ICSID). Revista de Informação Legislativa, Brasília, ano 35, n. 40, p. 87-93, out./dez. 1998.

PIT, H. M. Arbitration under the OECD model convention: follow-up under double tax conventions: an evaluation. 42 Intertax, n. 6-7, p. 445-469, 2014.

RIBEIRO, Marilda Rosado de Sá. Direito dos investimentos e o petróleo. Revista da Faculdade de Direito da UERJ, v. 1, p. 1-37, 2010.

RIBEIRO, Marilda Rosado de Sá. Sovereignty over natural resources investment law and expropriation: the case of Bolivia and Brazil. The Journal of World Energy Law and Business, v. 2, n. 2, p. 129-148, Jul. 2009

ROCHA, Augusto de Rezende. Parecer DAJ/138: criação de órgão de arbitragem internacional, BIRD. Washing- ton: BIRD, 1964.

ROTHMANN, Gerd Willi. A denúncia do acordo de bitributação Brasil-Alemanha e suas consequências. In: ROCHA, Valdir de Oliveira. Grandes questões de direito tributário. São Paulo: Dialética, 2005. v. 9.

SANTIAGO, Igor Mauler. Direito tributário internacional: métodos de solução de conflitos. São Paulo: Quartier Latin, 2006.

SCHOUERI, Luís Eduardo. Arbitragem no Direito Tributário Internacional. Revista Direito Tributário Atual, São Paulo, v. 23, p. 302-320, 2009.

SOUZA, Henrique Coutinho de. O aperfeiçoamento dos métodos de solução de controvérsias nos tratados contra bitributação firmados pelo Brasil à Luz da convenção modelo da OCDE. Revista Direito Tributário Atual, São Paulo, p. 124-141, 2014.

TIBÚRCIO, Carmen. A arbitragem no direito brasileiro: o histórico e lei 9.307/96. Revista de Processo, São Paulo, v. 104, p.79-99, 2001.

TIBÚRCIO, Carmen. Arbitragem de investimento no Brasil In: RIBEIRO, Marilda Rosado de Sá (Org.) Direito internacional dos investimentos. Rio de Janeiro: Renovar, 2014. p. 233-270.

VOGEL, Klaus. On double taxation conventions: a commentay to the OECD, UN and U.S. model conventions for the avoidance of double taxation of income and capital, with particular reference to german treaty practice. Boston: Kluwer, 1998.

XAVIER JÚNIOR, Ely Caetano. Direito internacional dos investimentos e o Brasil: uma perspectiva a partir do padrão de tratamento justo e equitativo. 2014. 279 f. Dissertação (Mestrado) - Faculdade de Direito, Universidade Estadual do Rio de Janeiro, Rio de Janeiro, 2014.

XAVIER, Alberto. Direito tributário internacional do Brasil. 8. ed. Rio de Janeiro: Forense, 2015.

ZIEGLER, Andreas R.; GRATTON, Louis-Philippe. Investment assurance In: MUCHLINSKI, Peter; ORTINO, Federico; SCHREUER, Christoph (Org.). The Oxford bandbook of international investment law. Oxford: Oxford University, 2008. p. 524-548. 
Para publicar na Revista de Direito Internacional, acesse o endereço eletrônico www.rdi.uniceub.br ou www.brazilianjournal.org.

Observe as normas de publicação, para facilitar e agilizar o trabalho de edição. 